\title{
O MÍNIMO EXISTENCIAL
}

\section{THE RIGHT TO BASIC CONDITIONS OF LIFE}

\section{Daniel Sarmento ${ }^{1}$}

\section{Resumo}

O presente artigo tem como objetivo analisar o direito ao mínimo existencial, como componente do princípio da dignidade da pessoa humana na ordem constitucional brasileira. O texto discute os fundamentos filosóficos do direito ao mínimo existencial, o seu conteúdo jurídico e os limites e possibilidades de sua proteção judicial.

Palavras-Chave: Mínimo existencial, direitos fundamentais, dignidade da pessoa humana, reserva do possível, ponderação de interesses, diálogos institucionais.

\section{Abstract}

This article aims to discuss the right to basic conditions of life, as a component of the principle of human dignity in the Brazilian constitutional order. The article discusses the philosophical foundations of the right to basic conditions of life, its legal content as well as the limits and possibilities of its judicial protection.

Keywords: right to basic conditions of life, fundamental rights, human dignity, minimum core, balancing of rights, institutional dialogues.

\footnotetext{
1 Professor Titular de Direito Constitucional da Universidade do Estado do Rio de Janeiro. Pós-doutorado na Universidade de Yale - EUA (2006). Coordenador da Clínica de Direitos Fundamentais da Faculdade de Direito da UERJ - Clínica UERJ Direitos. E-mail: sarmento_daniel@yahoo.com.br
} 


\section{INTRODUÇÃO}

"Parece duro que, pela falta de habilidade que não consegue superar, apesar de todos os seus esforços, um artesão passe fome. Parece duro que um trabalhador, incapacitado pela doença de competir com os mais fortes, tenha que suportar privações. Parece duro que viúvas e órfãos sejam deixados à própria sorte, para que lutem pela sua vida ou morte. Mas, quando observados não de modo isolado, mas em conexão com os interesses universais da humanidade, essas duras fatalidades parecem ser da mais elevada benevolência" (SPENCER, 1958, p. 137).

O texto acima, que causa engulhos até em pessoas de coração menos sensível, é de Herbert Spencer, filósofo inglês do século XIX, criador do darwinismo social, que sustentava que qualquer tipo de intervenção do Estado ou da sociedade voltada para a proteção das pessoas mais vulneráveis deveria ser repelida, por atentar contra o interesse geral de que apenas os mais aptos sobrevivam. As ideias de Spencer exerceram grande influência na Economia, na Filosofia Política e até mesmo no Direito Constitucional. Em um dos mais conhecidos votos divergentes da história do constitucionalismo norte-americano, Oliver Wendell Holmes, no início do século passado, protestou contra a adesão dos juízes da Suprema Corte à filosofia de Spencer, que ele não conseguia entrever na Constituição do país (ESTADOS UNIDOS, Suprema Corte, 1905).

A garantia jurídica do mínimo existencial corresponde à absoluta rejeição dessa filosofia social-darwinista. Não é de todo nova a compreensão de que o Estado e a sociedade devem prover as condições materiais básicas para os necessitados, que não tenham condições de se sustentar. Gerardo Pisarello aludiu à existência, já na Antiguidade e na Idade Média, de "diferentes mecanismos institucionais, embora não necessariamente estatais, voltados a aliviar situações prolongadas de pobreza e a assistir aos grupos mais necessitados" (PISARELLO, 2007, p. 20). Há também quem localize a origem dessa noção nas Poor Laws inglesas, existentes desde o século XVI, especialmente a partir da Speedhamland Law, de 1795, que suprimiu o condicionamento ao trabalho obrigatório para a assistência social aos desamparados (PEREIRA, 2000, p. 103-106). A Constituição francesa de 1793 já proclamava, em seu artigo 21, o direito aos socorros públicos, e preceito similar foi reproduzido pela Carta brasileira de 1824 (art. 179, XXXI), o que levou Paulo Bonavides e Paes de Andrade (1991, p. 100) a apontarem a "sensibilidade precursora para o social" da nossa Constituição imperial. Foi, porém, a partir do constitucionalismo social, inaugurado pela Constituição mexicana de 1917 e pela Constituição de Weimar de 1919, que a concepção de que cabe ao Estado garantir os direitos sociais ganhou contornos mais claros. 
É provável que a primeira formulação jurídica do direito ao mínimo existencial se deva a um jurista brasileiro - e não a um alemão, como geralmente se afirma. Já em 1933, Pontes de Miranda se referiu à existência de um direito público subjetivo à subsistência dentre o elenco dos "novos direitos do homem" que compreenderia o que chamou de "mínimo vital". Nas suas palavras,

Como direito público subjetivo, a subsistência realiza, no terreno da alimentação, das vestes e da habitação, o standard of living segundo três números, variáveis para maior indefinidamente e para menor até o limite, limite que é dado, respectivamente, pelo indispensável à vida quanto à nutrição, ao resguardo do corpo e à instalação.

É o mínimo vital absoluto. Sempre, porém, que nos referirmos ao mínimo vital, deve-se entender o mínimo vital relativo, aquele que, atentando-se às circunstâncias de lugar e de tempo, se fixou para cada zona em determinado período (...). O mínimo vital relativo tem de ser igual ou maior que o absoluto.

O direito à subsistência torna sem razão de ser a caridade, a esmola, a humilhação do homem ante o homem. (...) Não se peça a outrem, porque falte; exija-se do Estado, porque êste deve. Em vez da súplica, o direito (PONTES DE MIRANDA, 1933, p. 28-30).

Sem embargo, é certamente marcante na trajetória do Direito Constitucional a formulação germânica do direito ao mínimo existencial, ocorrida no segundo pós-guerra, já sob a égide da Lei Fundamental de 1949. A ideia de que existe um direito fundamental ao mínimo existencial, proposta originariamente naquele país no início dos anos 50 por Otto Bachof $(1954$, p. 42) foi reconhecida pelo Tribunal Administrativo Federal alemão em 1954 (ALEMANHA, Tribunal Administrativo Federal, 1954) a partir da conjugação do princípio da dignidade da pessoa humana, da cláusula do Estado Social e dos direitos à liberdade e à vida. Em 1975, o direito foi afirmado em célebre decisão do Tribunal Constitucional germânico ${ }^{1}$ (ALEMANHA, Tribunal Constitucional Federal, 1975) em jurisprudência que se mantém até hoje. Posteriormente, tribunais constitucionais ou supremas cortes de diversos outros países, como Portugal ${ }^{2}$ (PORTUGAL, Tribunal Constitucional, 2002), Israel (BARAK, 2015, p. 288), Índia³ (MURALIDHAR, 2008) e Colômbia (ARANGO; LEMAITRE, 2002) recorreram, com algumas variações, ao mesmo conceito ou a construções similares (DALY, 2013).

No Brasil, ideias como as de Spencer não conquistam praticamente nenhum apoio na sociedade. Pelo menos no plano do discurso, parece existir certo consenso no sentido de que se deve assegurar a todos o acesso às condições materiais básicas para uma vida digna. $\mathrm{Na}$ atualidade, nenhum ator político relevante se insurge publicamente contra, por exemplo, o papel do Estado na prestação de serviços de saúde, educação, previdência e assistência social. Nada 
obstante, ainda não foi completamente extirpada a percepção, entranhada em nossa cultura (CARVALHO, 2004), de que tal atuação estatal não corresponde propriamente à concretização de um direito fundamental, mas sim a um suposto benefício, concedido de modo paternalista por algum governante ou autoridade, cuja efetiva fruição dependa de relações pouco republicanas de clientela e patronagem.

Esta última visão foi claramente enjeitada pela Constituição de 88 , da qual se extrai a garantia do mínimo existencial como direito fundamental. Tal ideia provém não apenas da positivação dos direitos sociais no texto constitucional, como também da consagração do princípio da dignidade da pessoa humana como fundamento do Estado e da ordem jurídica brasileira. A literatura jurídica nacional (TORRES, 2009; BARCELLOS, 2002, p. 201-308; SARLET, 2008, p. 11-54; CLÈVE, 2003, p. 151-161) é praticamente unânime ao apontar o acolhimento do direito ao mínimo existencial, o mesmo ocorrendo com a nossa jurisprudência. Esta, porém, é relativamente recente, e vem se difundindo a partir de célebre decisão proferida pelo STF em 2004 (BRASIL, Supremo Tribunal Federal, 2004). Como se verá adiante, tal como ocorre com o princípio da dignidade da pessoa humana, o mínimo existencial também tem sido usado algumas vezes de forma retórica e inflacionada pelo Judiciário brasileiro.

Apesar do seu reconhecimento normativo, o mínimo existencial não é de fato assegurado a parcelas expressivas da população brasileira, que não desfrutam de acesso efetivo a bens e direitos essenciais para uma vida digna. Legiões de pessoas ainda vivem na mais absoluta miséria, expostas à insegurança alimentar, sem acesso à moradia adequada, ao saneamento básico, à saúde e à educação de mínima qualidade. À margem das conquistas civilizatórias do Estado democrático de direito, ainda existe um "Brasil de baixo" - do qual nos falou Patativa do Assaré - em que a regra é a privação, e onde os direitos não são "para valer". Além de acarretar injusto sofrimento às suas vítimas, esse quadro acaba também comprometendo a capacidade de tais pessoas de exercerem, de forma plena e consciente, os seus direitos civis e políticos.

Portanto, embora existam poucas dúvidas entre nós sobre a existência de uma garantia constitucional do mínimo existencial, a efetividade da Constituição, também neste particular, deixa muitíssimo a desejar. Há ainda um abismo entre as suas promessas generosas e a realidade da vida de vastos segmentos da população brasileira, que sobrevivem em condições francamente indignas. 


\section{FUNDAMENTOS FILOSÓFICOS PARA O MÍNIMO EXISTENCIAL}

Ao longo da história, a garantia de condições básicas de vida para os setores mais vulneráveis da população decorreu, muitas vezes, não de preocupações morais com os seus direitos ou bem-estar, mas do medo de convulsões sociais que pudessem abalar o status quo. Foi assim, por exemplo, com a rede de proteção social construída pelo chanceler conservador Otto von Bismarck, na Alemanha do final do século XIX (ZAMBITTE, 2011, p. 72-77). Nada obstante, neste momento o foco está centrado nos fundamentos que justificam o mínimo existencial, e não nas causas históricas que ensejaram o seu reconhecimento.

$\mathrm{Na}$ contemporaneidade, existe razoável convergência entre as mais variadas teorias políticas no sentido da necessidade de garantia das condições materiais básicas de vida para todos ${ }^{2}$. Há, contudo, significativas diferenças a propósito não só da justificativa para essa garantia, como também da sua extensão e forma de proteção.

Na minha leitura, os fundamentos para reconhecimento do direito ao mínimo existencial podem ser instrumentais ou independentes. Os fundamentos instrumentais apontam que o mínimo existencial deve ser assegurado para que, algum outro princípio ou objetivo, seja promovido (ABRAMOVICH; COURTIS, 2004, p. 200-220). Os princípios mais frequentemente invocados são a liberdade e a democracia. Já os fundamentos independentes postulam que o mínimo existencial deve ser garantido porque a sua denegação representa, em si mesma, uma grave injustiça, independentemente dos efeitos que possa ter sobre outros valores. A seguir, passo a examinar as referidas linhas argumentativas.

\section{Mínimo Existencial e Liberdade}

Há uma leitura tradicional sobre a liberdade, que afirma que este valor é restringido a cada vez que o Estado atua para promover a igualdade ou garantir direitos positivos para os segmentos mais vulneráveis da população. Isso porque - diz o argumento - a atuação do Estado importa em intervenção heterônoma sobre as relações sociais ou, no mínimo, em tributação da atividade econômica privada, destinada à obtenção dos recursos necessários ao financiamento das prestações e serviços estatais. Com isso, haveria restrição à liberdade individual (NOZICK, 1994). Nessa perspectiva, a garantia do mínimo existencial entraria em conflito com a liberdade (BERLIN, 2002, p. 231). 
Contudo, esta é uma visão excessivamente formalista da liberdade, que ignora os constrangimentos reais que impedem que as pessoas realizem e implementem as suas escolhas de vida. A liberdade não deve ser concebida como a mera ausência de constrangimentos externos impostos pelo Estado à ação dos agentes, mas como a possibilidade real de cada pessoa concreta tomar decisões sobre a sua própria vida e de segui-las. Foi sob essa perspectiva que diversos filósofos e juristas contemporâneos justificaram a garantia do mínimo existencial, fortes no argumento de que, sem o atendimento de certas condições materiais básicas, se esvazia por completo a liberdade, pela inviabilidade do seu efetivo exercício no mundo real (GEWIRTH, 2005, p. 219-236; NINO, 2004, p. 211-220; MICHELMAN, 1999, p. 119-132; BÖCKENFÖRDE, 1993, p. 74). O argumento também tem ressonância na jurisprudência constitucional comparada. A Suprema Corte de Israel, por exemplo, reconheceu um direito à subsistência com dignidade, afirmando que, "sem condições materiais mínimas, uma pessoa não tem a capacidade de criar, de ter aspirações, de fazer escolhas e de exercitar as suas liberdades" (ISRAEL, Suprema Corte, 2012).

Na filosofia política, o ponto foi elaborado com densidade por John Rawls. Como se sabe, Rawls foi o mais importante teórico do liberalismo igualitário, corrente da filosofia política que se notabiliza pela tentativa de articular de modo coerente a mais ampla garantia das liberdades públicas e existenciais com a promoção da igualdade material e da justiça social ${ }^{4}$. As suas ideias vêm exercendo enorme influência não só no âmbito da filosofia, mas até mesmo no Direito Constitucional (MICHELMAN, 1999, p. 394-425; VIEIRA, 1999; CITTADINO, 1999; SOUZA NETO, 2006). Pode-se dizer que elas redefiniram os próprios termos do debate contemporâneo sobre a filosofia política a partir dos anos 70 do século passado.

Em sua obra seminal A Theory of Justice, Rawls (1971) formulou princípios que deveriam reger as instituições básicas de uma sociedade justa. Para justificar racionalmente os seus princípios, Rawls recorreu à ideia de contrato social: os princípios da justiça seriam aqueles que resultassem de um acordo hipotético entre pessoas recobertas por um "véu da ignorância", que as impediria de conhecer as suas próprias características, posição social e interesses. A observância desse procedimento asseguraria, segundo Rawls, um resultado imparcial, aceitável para todos.

De acordo com o autor, as partes do contrato chegariam a dois princípios de justiça. O primeiro princípio (princípio da liberdade), ao qual Rawls atribuiu prioridade absoluta (prioridade léxica, nas suas palavras), concede a cada pessoa o mais amplo conjunto de liberdades básicas que seja compatível com o reconhecimento dos mesmos direitos para todos os demais. Só depois de assegurado plenamente este primeiro princípio, passa-se ao segundo, que Rawls designou de 
princípio da diferença, segundo o qual as desigualdades econômicas e sociais devem ser ordenadas de modo a que (a) sejam sempre mantidas oportunidades abertas para todos, em condições equitativas; e (b) o arranjo traga o maior benefício possível às pessoas mais desfavorecidas.

Ocorre que, para Rawls, apenas o princípio da liberdade deve ser reconhecido no plano constitucional. Formulando a sua teoria a partir das pré-compreensões norte-americanas sobre o papel limitado das constituições, Rawls relegou a realização do princípio da diferença, que trata da justiça social, para o âmbito da legislação ordinária. Portanto, para ele, numa sociedade justa os recursos devem ser distribuídos de modo que cada pessoa tenha bens primários muito superiores ao mínimo existencial (que Rawls designava de mínimo social). Nada obstante, Rawls não cogitava, àquela altura, em um direito constitucional ao mínimo existencial, entrincheirado perante as deliberações políticas, já que a implementação do mínimo dependeria de decisões legislativas.

Essa sua posição suscitou diversas críticas, como a formulada pelo constitucionalista norteamericano Frank Michelman (1989, p. 345 ss.). Este afirmou, dentre outros pontos, que a teoria de Rawls não se sustentaria em sociedades que não fossem "bem ordenadas" - como as que existem em países pobres - e que ela se baseara em uma concepção incorpórea e irreal de pessoa, não atentando aos pressupostos indispensáveis para que indivíduos concretos exerçam de fato as suas liberdades básicas.

Como fez também em outras questões, John Rawls, em diálogo com seus críticos, reformulou parcialmente a sua teoria para afirmar que os mínimos sociais seriam um pressuposto para aplicação do primeiro princípio de justiça, que cuidou das liberdades básicas. Na sua obra $O$ Liberalismo Político, publicada em 1993, ele afirmou:

(...) o primeiro princípio, que trata dos direitos e liberdades fundamentais, pode sem muitos problemas ser precedido de um princípio lexicamente anterior que prescreva a satisfação das necessidades básicas dos cidadãos, ao menos na medida em que satisfazê-las seja necessário para que eles entendam e tenham condições de exercer estes direitos e liberdades de forma efetiva (RAWLS, 2011, p. 8).

Daí porque a garantia do mínimo existencial passou a se qualificar, para Rawls, como "conteúdo constitucional essencial" (constitutional essential), devendo ser diferenciada dos princípios sobre justiça social, que, segundo ele, continuariam relegados ao plano da legislação infraconstitucional (RAWLS, 2011, p. 270). Outro autor que fundamentou a garantia do mínimo existencial na liberdade foi o alemão Robert Alexy. Ao contrário de Rawls, que construiu a sua teoria a partir da filosofia política, Alexy alicerçou a sua tese sobre o mínimo existencial no campo da dogmática constitucional, em diálogo com a jurisprudência da Corte Constitucional germânica. 
Ao tratar da questão, Alexy partiu da compreensão, que desenvolveu longamente, de que os direitos fundamentais são princípios compreendidos como mandados de otimização, que devem ser realizados na medida das possibilidades fáticas e jurídicas existentes (ALEXY, 2008). Na presença de conflitos entre princípios, deve-se recorrer, segundo Alexy, à técnica da ponderação de interesses, baseada na aplicação do princípio da proporcionalidade.

Diante da ausência de direitos fundamentais sociais na Constituição alemã, Alexy se vale da ideia de liberdade fática para justificar a sua proteção. Ele parte da premissa de que a liberdade fática tem importância extraordinária para o indivíduo, pois, sem ela, as liberdades jurídicas não passariam de "fórmula vazia" (ALEXY, 2008, p. 506). Ademais, citando decisão do Tribunal Constitucional alemão, aduziu que o sistema de direitos fundamentais é "a expressão de um sistema de valores, em cujo centro se encontra o livre desenvolvimento da personalidade humana e de sua dignidade no seio da comunidade social" (ALEXY, 2008, p. 506). Daí porque "os direitos fundamentais, se o seu escopo for o livre desenvolvimento da personalidade humana, também estão orientados para a liberdade fática, ou seja, também devem garantir os pressupostos para do exercício das liberdades jurídicas" (ALEXY, 2008, p. 506).

Todavia, Alexy reconhece que a garantia da liberdade fática enseja diversos problemas. 0 primeiro vem do fato de que a sua proteção judicial conflita com a competência conferida ao legislador para a definição das políticas sociais e para a eleição de prioridades no campo dos gastos públicos, haja vista os custos financeiros dos direitos prestacionais. O segundo deriva do reconhecimento de que a proteção dos direitos sociais tende a colidir com outros direitos. Uma dessas colisões resulta da necessidade de elevação da carga tributária para financiamento dos direitos a prestações materiais, o que repercute sobre a propriedade privada.

Para resolver esses conflitos, Alexy recorre mais uma vez à técnica da ponderação, salientando:

(...) a questão acerca de quais direitos fundamentais sociais o indivíduo definitivamente tem é uma questão de sopesamento entre princípios. De um lado está sobretudo o princípio da liberdade fática. Do outro lado estão os princípios formais, da liberdade decisória do legislador democraticamente legitimado e o princípio da separação de poderes, além de princípios materiais, que dizem respeito sobretudo à liberdade jurídica de terceiros, mas também a outros direitos fundamentais sociais e interesses coletivos (ALEXY, 2008, p. 512).

Alexy afirma que essa ponderação resulta no reconhecimento de um direito fundamental definitivo ao mínimo existencial (ALEXY, 2008, p. 512). Ou seja, para ele, o mínimo existencial é o resultado do sopesamento de princípios, não se submetendo a qualquer ponderação posterior. 
No Brasil, o principal difusor da tese de que o mínimo existencial se assenta na garantia da liberdade é o Professor Ricardo Lobo Torres, precursor do estudo do assunto na doutrina nacional contemporânea. Ricardo Lobo Torres, como pensador liberal, sempre se insurgiu contra a concepção amplamente majoritária no país de que os direitos sociais são dotados de fundamentalidade. Sua posição na matéria se liga a uma crítica veemente à ideia de Estado Social e ao modelo de constituição dirigente, que Ihe é correlato. Nada obstante, Lobo Torres afirmou, nos muitos textos que escreveu sobre o assunto, que o mínimo existencial possui fundamentalidade em razão da sua ligação intrínseca com a liberdade (TORRES, 2003, p. 5-6) - embora ele também faça referência a outros princípios para justificá-la, como a dignidade da pessoa humana e a cidadania. Para o autor,

O direito às condições mínimas de existência digna constitui o conteúdo essencial dos direitos da liberdade, ou direitos humanos, ou direitos individuais, ou direitos naturais, formas diferentes de expressar a mesma realidade. (...) O mínimo existencial exibe as características básicas dos direitos da liberdade: é pré-constitucional, posto que inerente à pessoa humana; (...) é negativo, pois exibe o status negativus que protege o cidadão contra a constrição do Estado ou de terceiros; cria também o status positivus libertatis, que gera a obrigação de entrega de prestações estatais individuais para a garantia da liberdade e das suas condições essenciais; postula garantias institucionais e processuais que provocam custos para o Estado; é plenamente justiciável; independem de complementação legislativa, tendo eficácia imediata (TORRES, 2009, p. 39-40).

$\mathrm{O}$ argumento da liberdade em favor do mínimo existencial é bastante persuasivo. Afinal, parece incontroverso que o acesso a condições materiais básicas é realmente indispensável para capacitar as pessoas ao exercício das suas liberdades (NUSSBAUM, 2011; SEN, 1999). Um analfabeto encontrará dificuldades praticamente insuperáveis para se expressar e ter acesso à informação. Uma pessoa doente ou faminta não conseguirá realizar as suas escolhas existenciais mais importantes, pois a sua condição absorverá todas as suas forças e energias. Portanto, a liberdade para pessoas reais realmente pressupõe a garantia do mínimo existencial.

\section{Mínimo existencial e democracia}

Existem infindáveis polêmicas a propósito do conceito de democracia. Porém, é praticamente consensual na filosofia política contemporânea que a democracia não se resume à realização periódica de eleições com sufrágio universal. O regime democrático se assenta na compreensão de que os cidadãos devem ter a igual oportunidade de participar do processo de formação da vontade da comunidade política que integram. 
Ocorre que, para que essa participação do cidadão possa ser efetiva, ele precisa ter condições materiais mínimas para exercê-la. É evidente que o indivíduo com baixo nível de instrução deve ter plenos direitos políticos, com ampla possibilidade de participar do autogoverno popular. Contudo, o seu déficit de escolaridade tende a comprometer a sua capacidade de se informar adequadamente sobre os assuntos públicos e de participar, como um igual, nas deliberações sociais (CANOTILHO, 1998, p. 432). O mesmo ocorre com pessoas miseráveis, em situação de penúria. Estas, ademais, se inserem frequentemente em relações de dependência material com terceiros mais poderosos, o que pode afetar gravemente a sua liberdade na esfera política. A democracia, portanto, só funciona adequadamente quando são asseguradas a todos as condições materiais básicas de vida (MÜLLER, 2002, p. 567-607), que possibilitem a instauração na esfera pública de relações simétricas entre cidadãos tratados como livres e iguais (SOUZA NETO, 2006, p. 242-258).

A relação entre democracia e garantia do mínimo existencial foi elaborada por vários autores (FABRE, 2000, p. 110-151; OLIVEIRA, 2013; CRUZ, 2008, p. 87-136; GARGARELLA, 2008, p. 207-229) cabendo destacar, pela sua importância, as ideias do filósofo alemão Jürgen Habermas.

Habermas é um pensador complexo, que deu diversas contribuições seminais para as mais diversas áreas do conhecimento, inclusive para o Direito Constitucional ${ }^{11}$. Não é este o espaço adequado para examinar as projeções do seu pensamento no campo da teoria constitucional, mas cabe assinalar, de modo muito superficial e conciso, que elas gravitam em torno da tentativa de conciliação da tradição constitucionalista liberal, que enfatiza a importância do respeito aos direitos individuais (autonomia privada), com a tradição democrática, que postula a defesa da soberania popular (autonomia pública) (HABERMAS, 2002, p. 285-298). A démarche constitucional habermasiana tem como norte a elaboração de um modelo em que as autonomias pública e privada se articulam e complementam, sendo concebidas como "co-originárias" (HABERMAS, 2003, p. 153-173).

Uma das premissas habermasianas é a de que a legitimidade do Direito, nas sociedades contemporâneas marcadas pelo pluralismo, não pode se fundar em qualquer concepção material de justiça. Para Habermas, tal contexto desloca a fonte de legitimidade do Direito para o processo democrático de produção das normas, que deve garantir a todos os cidadãos as condições necessárias para uma igual participação na deliberação pública (HABERMAS, 1997, p. 190-210). O Direito legítimo, neste cenário, é aquele em que os cidadãos podem se enxergar não apenas como 
destinatários das normas, mas também como seus coautores. Daí a centralidade da democracia no edifício teórico habermasiano.

Para Habermas, a democracia não é apenas o governo das maiorias, nem resulta da simples agregação das preferências e interesses conflitantes dos cidadãos. A democracia habermasiana é deliberativa e se baseia no diálogo social entre pessoas livres e iguais, travado no espaço público. Nesse diálogo, deseja-se que o cidadão não atue como um agente econômico no mercado, procurando a maximização dos seus próprios interesses, mas como alguém disposto a aprender com o outro e engajado numa empreitada cooperativa de busca de soluções para problemas comuns, que sejam racionalmente aceitáveis para todos os afetados (HABERMAS, 2002, p. 269-284). Na deliberação, todos devem poder expor seus argumentos e contra-argumentos, com liberdade e igualdade. O processo discursivo que se processa dessa forma não apenas racionaliza, como confere legitimidade às decisões tomadas. Mas, para que se instaure um ambiente propício a essas interações comunicativas, a garantia de direitos fundamentais se afigura indispensável.

A partir desse norte, Habermas elabora um catálogo desses direitos fundamentais, cuja observância configuraria pressuposto para a legitimidade do Direito estatal:

1. Direitos fundamentais que resultam da configuração politicamente autônoma do direito à maior medida possível de iguais liberdades subjetivas de ação. (...)

2. Direitos fundamentais que resultam da configuração politicamente autônoma do status de um membro numa associação voluntária de parceiros.

3. Direitos fundamentais que resultam imediatamente da possibilidade de postulação judicial de direitos e da configuração politicamente autônoma da proteção jurídica individual. (...)

4. Direitos fundamentais à participação, em igualdade de chances, em processos de formação de opinião e da vontade, nos quais os civis exercitam a sua autonomia pública e através dos quais eles criam direito legítimo. (...)

5. Direitos fundamentais a condições de vida garantidas social, técnica e ecologicamente, na medida em que isso for necessário para um aproveitamento, em igualdade de chances, dos direitos elencados em (1) até (HABERMAS, 1997, p. 159-160).

Os direitos listados em (1) a (4) abrangem as liberdades civis, a cidadania, o acesso à justiça e o direito à participação política. Habermas considera-os "fundamentados absolutamente" (HABERMAS, 1997, p. 160). Já o direito arrolado em (5), que corresponde ao mínimo existencial na sua dimensão não apenas social, como também ambiental - seria, segundo Habermas, fundamentado apenas de modo relativo. O seu papel é apenas instrumental: assegurar a 
possibilidade de efetiva fruição dos demais direitos, que, por sua vez, viabilizam o funcionamento da democracia deliberativa, conferindo legitimidade ao Direito 5 .

A elaboração habermasiana soma-se a outras que apontam a necessidade de garantia de condições sociais mínimas para que cada indivíduo possa atuar na esfera pública como cidadão. É difícil refutar essa conclusão. Porém, como se verá a seguir, os argumentos instrumentais em favor do mínimo existencial - fundados na liberdade ou na democracia -, conquanto corretos e relevantes, não são suficientes para fundamentá-lo em toda a sua extensão.

\section{Mínimo existencial, necessidades básicas e justiça: fundamentação independente}

Há justificativas não instrumentais para a proteção ao mínimo existencial que não concebem a sua garantia como um mero pressuposto para a fruição de outros direitos ou persecução de outras finalidades coletivas importantes. Elas partem da premissa de que a satisfação das necessidades materiais básicas de pessoas que não tenham condições de fazê-lo por si próprias é um componente central da ideia de justiça (DOYAL; GOUGH, 1991, p. 191-221; HELLER, 1996; PEREIRA, 2000) que justifica a sua proteção jurídica, inclusive no plano constitucional (LEIVAS, 2006, p. 123-140). Essas teorias não negam que a garantia do mínimo existencial seja vital para a promoção de outros direitos e valores, como a liberdade e democracia, mas tampouco condicionam tal garantia aos referidos objetivos. Por isso, chamo esta outra perspectiva sobre o mínimo existencial - à qual me filio - de independente.

Uma contribuição importante nessa linha é do filósofo alemão Ernst Tugendhat em sua obra Lições sobre Ética. Tugendhat baseia-se na ideia de que, ao contrário do que preconiza o liberalismo, o fundamento último dos direitos não é a garantia da liberdade, mas o atendimento das necessidades humanas. A liberdade, para ele, seria apenas mais uma necessidade humana, conquanto extremamente importante. Para Tugendhat, a obsessão com a liberdade tem viés ideológico e parte de premissas equivocadas, articuladas pelo contratualismo, que erigiu princípios supostamente universais a partir dos interesses dos indivíduos mais fortes. Nas suas palavras,

No interior da discussão jurídico-constitucional sobre direitos humanos ou fundamentais o conceito de liberdade exerce tradicionalmente o papel fundamental. A ideologia que estava atrás disso era que o ser humano 'na condição natural' - sem Estado - seria em princípio livre; com a fundação de um Estado ele Ihe deu parte de sua liberdade; a tarefa do Estado legítimo consiste em assegurar reciprocamente a liberdade dos indivíduos, conquanto que ela não prejudique a liberdade dos outros. (...) A orientação unilateral a partir da liberdade é, contudo, falsa até para a tradição liberal, porque sobretudo o direito à vida e à integridade física não é um direito de 
liberdade. Além disso, a ideia de uma condição natural é, visto do ponto de vista moral, um mito ruim, porque ela parte exclusivamente dos adultos que têm condições de providenciar por si mesmos (...). Mas, fundamental para a pergunta pelos direitos que a gente tem somente pode ser o conceito da necessidade (ou interesse). O lugar da liberdade ficaria no ar se ela não fosse uma das necessidades fundamentais do indivíduo a ser reconhecida moralmente, da mesma forma que a necessidade da integridade física, mas também, p. ex., como a necessidade de ajuda, e de educação na fase da infância (...) bem como a necessidade da participação política (TUGENDHAT, 2000, p. 385-386).

Tugendhat argumenta que fundamentar os direitos sociais apelando apenas à liberdade - e o mesmo, penso eu, vale para a democracia - acaba deixando de fora aquelas pessoas que, por características pessoais, não têm como exercê-la, não pela ausência de condições materiais, mas por suas próprias características (TUGENDHAT, 2000, p. 388).

O autor está certo. A garantia do mínimo existencial é importante para a proteção e promoção da liberdade e da democracia, mas mesmo em hipóteses em que tais princípios não estejam em jogo, as condições materiais básicas de vida devem ser asseguradas. Não se deve cogitar, por exemplo, em privar do acesso ao mínimo existencial aqueles indivíduos especialmente vulneráveis, incapacitados para o exercício da autonomia pública ou privada, como crianças e pessoas com severa deficiência mental. A extrema vulnerabilidade desses sujeitos parece razão adicional para a proteção do mínimo existencial, e não o contrário. Isso mostra que o mínimo existencial não é só um instrumento para a consecução de outros fins, mas tem de receber proteção independente.

Nessa questão, uma consulta às nossas convicções morais mais profundas - à moda do procedimento do equilíbrio reflexivo de Rawls (1971, p. 46-53) - corrobora o argumento da independência. Quando nos deparamos com o sofrimento de uma pessoa faminta, sem-teto ou doente pela falta de acesso a tratamento de saúde, somos tomados pelo sentimento de injustiça, não porque percebemos ali alguma lesão à liberdade ou à democracia. É a própria privação de uma necessidade básica e o sofrimento injusto que ela enseja que nos causam a justa indignação.

A dependência do mínimo existencial em relação aos direitos civis e políticos parece derivar de uma indevida hierarquização entre esses direitos e os sociais. Mesmo autores situados no campo progressista, como Rawls e Habermas, ao tratarem dessa questão, parecem incorrer no velho cacoete do liberalismo-burguês de desvalorizar os direitos sociais em face dos individuais e políticos. Porém, além de não se sustentar sob o ângulo de uma moral crítica, no Brasil, essa concepção não encontra qualquer amparo, seja no ordenamento constitucional vigente, que não contempla hierarquia dessa natureza, seja em nossa cultura social. Nosso ethos, inclusive, parece 
apontar até no sentido oposto, da prioridade dos direitos sociais em face das liberdades, o que não deixa de ser igualmente problemático.

\section{O mínimo existencial fragiliza os direitos sociais?}

A teoria do mínimo existencial não é isenta de críticas. No Brasil, não têm maior relevo social, político ou jurídico as críticas conservadoras, contrárias à proteção constitucional do mínimo existencial. Porém, parece-me importante a objeção proveniente do lado oposto do espectro político, que afirma que a teoria é conservadora e fica aquém da Constituição de 88 no que concerne à proteção dos direitos sociais.

A crítica afirma que uma ordem constitucional justa deveria aspirar à justiça social, e não se contentar com a garantia do mínimo para aplacar a miséria. Nessa perspectiva, há quem associe o mínimo existencial a uma visão elitista e excludente, própria do neoliberalismo, que busca limitar a atuação do Estado no campo social e preservar a essência das estruturas econômicas do capitalismo (PEREIRA, 2000, p. 15). Ao invés de se contentar com migalhas - dizem esses críticos -, o jurista comprometido deveria usar as armas da Constituição para transformar o status quo, buscando muito mais do que a simples garantia das condições mínimas de subsistência para os miseráveis.

O argumento é relevante e deve ser considerado, especialmente se levarmos em conta as características do nosso ordenamento constitucional. Na seara jurídica, como já ressaltado, o mínimo existencial é uma construção da dogmática e jurisprudência alemãs, que serviram à proteção de um conteúdo básico de direitos sociais, no marco de uma Constituição que não previra esses direitos (KRELL, 2002, p. 60). Portanto, a garantia do mínimo representou um plus em relação ao texto constitucional germânico. Mas a Constituição brasileira, ao contrário, é pródiga na garantia de direitos sociais. Nesse contexto, será que a importação do conceito não acabaria operando aqui "com os sinais trocados", para restringir a eficácia dos direitos sociais e, com isso, limitar os potenciais transformadores da Constituição?

Só há como superar a crítica por meio da construção de uma teoria adequada sobre o mínimo existencial, que não a corrobore. O primeiro ponto que deve ser esclarecido é que o mínimo não pode se limitar às condições necessárias à sobrevivência física. Ele tem de ser mais amplo para abarcar as condições básicas para uma vida digna, abrangendo também o chamado "mínimo sociocultural" (SARLET; FIGUEIREDO, 2008, p. 21-22). Prestações materiais que não se 
afigurem indispensáveis para a sobrevivência física, mas sejam condições elementares para a vida digna, como, por exemplo, o acesso à educação básica, também devem estar abarcadas.

Por outro lado, é preciso compreender o papel do mínimo existencial na nossa ordem constitucional. Em primeiro lugar, ele não define as prestações materiais que devem ser asseguradas pelo Estado a cada indivíduo em condição de vulnerabilidade, mas apenas estabelece um piso, abaixo do qual não se pode descer. O legislador tem ampla liberdade para ir além do mínimo existencial, buscando concretizar pelos mais variados meios - prestação de serviços públicos, tributação, regulação das atividades econômicas etc. - uma realização mais plena da igualdade material.

Ademais, mesmo no plano constitucional, o mínimo existencial não pode ser empregado para justificar genericamente a denegação de prestações materiais previstas na própria Lei Fundamental, mas que nele não se insiram - e.g., benefícios previdenciários superiores ao salário mínimo, gratuidade das universidades públicas, 13으 salário para trabalhadores e servidores públicos etc. Ele não permite que o intérprete se converta em uma espécie de censor conservador do poder constituinte, com a faculdade de reduzir a proteção social conferida expressamente pela própria Constituição, para descartar ou negar eficácia a tudo aquilo que não repute tão essencial.

Em minha opinião, o mínimo existencial desempenha dois papéis muito importantes, e nenhum deles fragiliza a dimensão social da Constituição. O primeiro papel é o de fundamentar pretensões positivas ou negativas que visem a assegurar as condições materiais essenciais para a vida digna e que não estejam abrigadas por outros direitos fundamentais expressamente positivados. O mínimo pode lastrear pretensões ligadas, por exemplo, ao acesso à agua, à energia elétrica, ao vestuário adequado etc. É evidente que esse emprego do mínimo existencial não debilita os direitos sociais, pois agrega prestações e garantias adicionais ao seu elenco.

O outro papel é o de servir de parâmetro para a ponderação que é travada entre, de um lado, o direito reivindicado e, do outro, os princípios que com ele colidirem. É que os direitos prestacionais, conquanto exigíveis, não são absolutos, configurando, em geral, direitos subjetivos garantidos prima facie (SARMENTO, 2008, p. 565-563; BOROWSKY, 2003, p. 148-186; SARLET, 1999, p. 129-173; LEIVAS, 2006, p. 87-122). Por envolverem custos, eles dependem da alocação de recursos escassos, e é competência do legislador, também prima facie, a realização das escolhas sobre o que deve ser priorizado. Daí porque a adjudicação de direitos a prestações materiais envolve, com frequência, uma ponderação entre, de um lado, o direito postulado e, do outro, a separação de poderes e democracia, que dão sustentação à competência legislativa em questão. 
Nesse cenário, o mínimo existencial atua para reforçar, na ponderação, a proteção das pretensões que abrange em detrimento dos princípios contrapostos. O tema, que diz respeito à relação entre o mínimo existencial e a chamada "reserva do possível", será retomado e aprofundado em outro item. Aqui, importa apenas ressaltar que, na minha concepção, o mínimo existencial atua para fortalecer o "conteúdo em mínimo existencial" dos direitos no processo ponderativo, mas não para negar qualquer eficácia jurídica positiva aos direitos naquilo que excederem a esse mínimo. Esta é uma diferença importante entre a teoria sobre o mínimo existencial que sustento e a que foi elaborada por autores como Ricardo Lobo Torres (2009, p. 271-277) e Ana Paula de Barcellos (2002, p. 230 ss). O acolhimento da posição ora defendida afasta a crítica de que o mínimo existencial é incompatível com a busca da efetivação máxima dos direitos sociais prestacionais no quadro das possibilidades fáticas e jurídicas de cada sociedade.

Adotadas essas perspectivas, não creio que o mínimo existencial fragilize os direitos sociais ou dilua as pretensões emancipatórias da Constituição. Pelo contrário, a categoria fortalece e racionaliza o imperativo ético, constitucionalmente consagrado, de assegurar a todos as condições materiais básicas de vida. Talvez até fosse preferível falar não em mínimo existencial - pois a expressão denota efetivamente uma esfera minimalista de proteção -, mas em garantia de condições básicas para a vida digna. Porém, considerando que o uso da expressão já se disseminou, parece uma estratégia mais inteligente defini-la de modo mais generoso do que travar batalhas terminológicas com reduzida chance de êxito.

\section{SUJEITOS E CONTEÚDO DO DIREITO AO MÍNIMO EXISTENCIAL}

Como afirmado acima, o mínimo existencial corresponde às condições materiais básicas para uma vida digna. Trata-se de um direito fundamental derivado diretamente do princípio da dignidade da pessoa humana, que também se manifesta em boa parte dos direitos fundamentais sociais positivados pela Constituição de 88 , como saúde, educação, moradia, alimentação, previdência e assistência social etc., estando igualmente presente em alguns direitos individuais, como no acesso à justiça (BARCELLOS, 2002, p. 293-301).

Como dimensão do princípio da dignidade da pessoa humana, o direito ao mínimo existencial possui caráter universal, sendo titularizado por todas as pessoas naturais, independentemente de qualquer outra condição. Os presos - não importa a gravidade do crime que tenham eventualmente cometido ou de que estejam sendo acusados - não perdem, evidentemente, o direito ao mínimo existencial, que, não obstante, vem-lhes sendo 
sistematicamente denegado em todo o país, pelas condições absolutamente degradantes do nosso sistema carcerário. Os estrangeiros são também titulares do direito ao mínimo existencial. Daí porque se afigura patentemente inconstitucional o art. 70 do Decreto no 6.214/07, que, regulando o benefício de um salário mínimo mensal para pessoas com deficiência ou idosas em condições de miserabilidade - prestação prevista na Constituição (art. 203, V), que se enquadra inequivocamente no mínimo existencial -, limitou-o aos brasileiros natos ou naturalizados. As pessoas jurídicas, todavia, não são titulares do direito ao mínimo existencial, pois não são "fins em si mesmas", não possuindo dignidade intrínseca, diferentemente das pessoas naturais. Assim, devem ser criticadas as decisões do STJ que aludiram ao mínimo existencial de pessoas jurídicas, desnaturando e inflacionando o conceito ${ }^{6}$.

Além do Estado, os particulares também estão vinculados ao direito ao mínimo existencial (SARLET, 2000), embora com os matizes e ponderações que caracterizam a eficácia horizontal dos direitos fundamentais (SARMENTO, 2010; SARLET, 2000, p. 107-163; STEINMETZ, 2005; SILVA, 2005). A proteção ao mínimo existencial no contexto de relações privadas, afirmada em reiterados julgados da Corte Constitucional colombiana ${ }^{7}$, tem surgido com alguma frequência na jurisprudência brasileira, e a categoria já foi invocada, por exemplo, em casos envolvendo a impenhorabilidade da moradia (BRASIL, Superior Tribunal de Justiça, 2012) e de valores depositados em caderneta de poupança até 40 salários mínimos (BRASIL, Superior Tribunal de Justiça, 2013), em hipóteses em que se discutia a limitação da margem de consignação de empréstimos em folha de pagamento (BRASIL, Superior Tribunal de Justiça, 2012) e em discussões atinentes aos alimentos do Direito de Família (BRASIL, Superior Tribunal de Justiça, 2015). Como se verá abaixo, entendo que alguns desses usos não foram corretos.

O tema do conteúdo do direito ao mínimo existencial é complexo. A primeira observação importante é no sentido de que existem variações socioculturais significativas em relação ao que se concebe como necessidades básicas. Sociedades diferentes tendem a valorar de modo muito distinto determinados bens, de modo que o acesso a eles pode se afigurar essencial para a vida digna das pessoas em algumas delas e não em outras. $\mathrm{O}$ acesso à energia elétrica, que nos parece tão imprescindível no mundo moderno, pode não fazer sentido para algumas comunidades indígenas, cujos integrantes, no entanto, necessitam de muito mais espaço físico - o seu território tradicional - no qual consigam viver de acordo com as suas cosmovisões, que conformam a sua concepção própria de dignidade. 
Parece inquestionável a existência de necessidades materiais que decorrem da própria natureza humana, como o acesso à alimentação, à água, à moradia e à saúde. Todavia, até mesmo essas necessidades universais se sujeitam a importantes variações culturais: sabe-se, por exemplo, que o ser humano precisa diariamente de um determinado número de calorias para sobreviver com saúde, mas a concepção sobre qual é a alimentação adequada varia bastante entre, por exemplo, um hindu, um inuit e um norte-americano. Nesse sentido, a Comissão de Direitos Econômicos, Sociais e Culturais da ONU, ao definir, em seu Comentário-Geral no 12, qual é o conteúdo essencial do direito à alimentação adequada, afirmou que se trata da "disponibilidade de alimentação em quantidade e qualidade suficientes para a satisfação das necessidades de dieta dos indivíduos, livre de substâncias adversas e aceitáveis dentro de cada cultura" (parágrafo 8).

Além das variações culturais, a análise do mínimo existencial tem de levar em consideração também as necessidades de cada pessoa concreta. O mínimo existencial é uma categoria universalista, mas não remete ao universalismo abstrato, característico do direito liberal-burguês, cego às diferenças e especificidades de cada sujeito. Assim, uma determinada prestação pode integrar o mínimo existencial para uma pessoa, mas não para outra, tendo em vista a variação das respectivas necessidades básicas. Veja-se o exemplo do direito à saúde: é certo que se trata de um direito universal (art. 196, CF), e que a gratuidade do SUS vale para todos, inclusive para os ricos (art. 43 da Lei no 8.080/90). Porém, o não fornecimento de um medicamento indispensável para o tratamento de uma pessoa pobre, que não disponha dos recursos necessários para adquiri-lo por conta própria, pode significar um grave abalo à sua saúde ou até mesmo um sacrifício à sua vida. Já para outro indivíduo com a mesma patologia, que tenha, contudo, condições de custear o medicamento sem prejuízo da sua subsistência digna, a omissão estatal não terá efeitos similares: repercutirá no seu patrimônio, mas não ameaçará a sua saúde ou a sua vida. No primeiro caso, haverá violação do direito ao mínimo existencial, mas não no segundo.

Esses pontos - a sensibilidade em relação às necessidades de cada sujeito e o foco prioritário nos excluídos - são muito enfatizados na riquíssima jurisprudência sobre o mínimo existencial da Corte Constitucional colombiana (LEMAITRE, 2005). No Brasil, porém, nem sempre esses aspectos são tomados em conta, o que pode levar o mínimo existencial a se desnaturar em mais um artifício retórico para a garantia de direitos - por vezes até de privilégios não universalizáveis - à classe média e aos abonados (FERRAZ, 2011, p. 76-102; SILVA, 2008, p. 587599; BARROSO, 2008, p. 875-904). 
Essa preocupação com as especificidades de cada sujeito não infirma o foco no potencial de universalização do mínimo existencial (FONTE, 2013, p. 215-216) - corolário, aliás, do caráter igualitário do princípio da dignidade da pessoa humana. Em outras palavras, o mínimo deve possuir um conteúdo universalizável no sentido de que as suas prestações devem ser extensíveis a todos os que se encontrarem na mesma situação - aí considerados tanto os aspectos objetivos como também os subjetivos. Não há, por exemplo, como conceber como mínimo existencial o direito ao melhor tratamento de saúde oferecido para uma doença grave em qualquer hospital do mundo inteiro, por mais proibitivo que seja o seu custo, pois não seria viável, mesmo em um país rico, universalizar um direito desta natureza.

De todo modo, como já se consignou acima, a proteção do mínimo existencial não se esgota na garantia das necessidades humanas fisiológicas, sem as quais se inviabilizaria a própria sobrevivência física. O que se almeja assegurar não é apenas a sobrevivência física dos indivíduos, mas, muito além disso, a sua própria dignidade ${ }^{8}$. Por isso, é inequívoco que o mínimo existencial abrange aspectos como o acesso à educação, a vestimentas apropriadas (mesmo em climas quentes) etc. É o que vem entendendo a jurisprudência brasileira, que, em caso atinente ao direito ao atendimento em creche e pré-escola, deixou assentado:

O mínimo existencial não se resume ao mínimo vital, ou seja, o mínimo para se viver. O conteúdo daquilo que seja o mínimo existencial abrange, também, as condições socioculturais, que, para além da questão da mera sobrevivência, asseguram ao indivíduo um mínimo de inserção na vida social (BRASIL, Superior Tribunal de Justiça, 2010).

Há quem afirme que o mínimo existencial corresponde ao núcleo essencial dos direitos sociais ou mesmo dos direitos fundamentais (TORRES, 2008). Existe, na atualidade, um esforço no sentido de definição do conteúdo essencial dos direitos sociais (ALMEIDA, 2014, p. 245-263; YOUNG, 2008, p. 113-175). Na esfera internacional, a liderança nesse processo tem cabido ao Comitê de Direitos Econômicos, Sociais e Culturais da ONU, que, no seu Comentário-Geral no 3, de 1990, afirmou o dever dos Estados de garantirem imediatamente o minimum core dos direitos sociais previstos no Pacto Internacional dos Direitos Econômicos, Sociais e Culturais, e vem editando diversos comentários-gerais sobre direitos específicos, buscando definir o que seria, em cada caso, esse núcleo mínimo.

Nada obstante, concordo com Ingo Wolfgang Sarlet e Mariana Filchtiner Figueiredo (2008, p. 25-26) no sentido de que tais categorias até possuem pontos importantes de contato, mas não se confundem. Em primeiro lugar, porque nem todos os direitos sociais constitucionalmente garantidos se voltam à garantia de condições materiais básicas sem as quais não há vida digna. 
Veja-se, por exemplo, o direito ao 13으 salário, que, conquanto positivado na Constituição como direito social (art. 70, VIII, CF) não guarda qualquer relação com as condições básicas para a vida com dignidade.

Ademais, há prestações ligadas ao mínimo existencial que não foram contempladas em qualquer dos demais direitos positivados pela Constituição, não estando, portanto, garantidas pelos respectivos núcleos essenciais - e.g., direito ao vestuário adequado, mesmo onde o clima não torne o uso da roupa essencial para a proteção da saúde e da vida. Finalmente, a categoria do núcleo essencial se sujeita a muitas leituras e interpretações (SILVA, 2009; PEREIRA, 2009, p. 365384). Uma delas, provavelmente hegemônica na literatura jurídica nacional - a chamada "teoria relativa" sobre o conteúdo essencial - o reduz ao que "sobra" do direito fundamental em cada caso concreto depois de uma ponderação com princípios eventualmente colidentes, pautada pelos critérios da proporcionalidade. A construção do núcleo essencial, nessa perspectiva, rege-se por lógica muito distinta da que dirige o reconhecimento do mínimo existencial, pois esta não se liga ao sopesamento de princípios contrapostos, mas sim à identificação de necessidades materiais básicas para a vida com dignidade.

Na doutrina, há tentativas de definição dos direitos e prestações que compõem o mínimo existencial. No país, a mais conhecida delas foi formulada por Ana Paula de Barcellos (2002, p. 247301) com o meritório objetivo de fornecer parâmetros para a atuação judicial, ao preestabelecer quais seriam as prestações materiais que, independentemente de previsão legal e da existência de verbas orçamentárias correspondentes, poderiam ser asseguradas pelo Judiciário num cenário de escassez de recursos. A sua lista compreende a educação fundamental, a saúde básica - que abarcaria o saneamento, o atendimento materno-infantil, as ações de medicina preventiva e prevenção epidemiológica -, a assistência social aos desamparados e o acesso à justiça - este último visando à tutela dos demais direitos.

Entendo, porém, que o elenco de Barcellos é incompleto, por excluir completamente alguns direitos umbilicalmente ligados à dignidade humana, como a moradia. Além disso, ele é insuficiente em alguns direitos que contempla, como na saúde, cuja faceta curativa foi quase integralmente afastada, ou na educação, em que não se abarcou a creche e pré-escola, nem tampouco o ensino médio. Ademais, a lista esvazia uma das mais importantes funções do mínimo existencial, que é a de lastrear demandas que, conquanto ligadas à dignidade humana, não estão inseridas em qualquer outro direito fundamental expressamente positivado na Constituição. Afinal, 
educação, saúde, assistência aos desamparados e acesso à justiça já estão devidamente contemplados em direitos específicos inseridos no catálogo da Carta de 88.

Não vejo como definir um elenco fechado de direitos ou prestações componentes do mínimo existencial. Parece-me preferível preservar a abertura inerente à categoria, inclusive para que ela possa se estender a necessidades básicas cujo reconhecimento resulte de evoluções sociais no plano material ou cultural-valorativo.

Nessa senda, é interessante observar que a jurisprudência vem reconhecendo prestações ligadas ao mínimo existencial que não estão expressamente positivadas na Constituição. O STF, por exemplo, já se valeu do mínimo existencial para proteger o direito de acesso à água no semiárido nordestino (BRASIL, Supremo Tribunal Federal, 2014) e o STJ já o invocou para afirmar a obrigação do Estado de instalar rede de tratamento de esgoto (BRASIL, Superior Tribunal de Justiça, 2014). Aliás, em relação ao direito à água, a Corte Constitucional colombiana tem riquíssima jurisprudência baseada no mínimo vital (COLÔMBIA, Corte Constitucional, 2008, 2010, 2014).

Outro ponto muito importante diz respeito à competência para a definição das prestações ligadas ao mínimo existencial. Não há dúvida, por um lado, que, sendo o mínimo existencial um direito fundamental, a sua proteção não pode ser deixada ao alcance das maiorias legislativas de ocasião. Na hipótese, além da supremacia da Constituição em face das decisões dos poderes constituídos, pode-se invocar também o argumento substantivo ligado à democracia: a liberdade de conformação legislativa no que concerne à definição das políticas públicas tem o seu principal fundamento no princípio democrático, e, como se viu acima, a democracia depende de pressupostos materiais, dentre os quais a garantia do mínimo existencial para a população carente. Daí porque não há como reconhecer uma plena liberdade para o legislador nessa área.

Nada obstante, não há dúvida de que existe um campo legítimo para deliberação política em relação também ao mínimo existencial. Pense-se no exemplo do direito à alimentação adequada, que certamente compõe o mínimo existencial. Existem diversas formas igualmente legítimas para se buscar a sua garantia, e.g., fornecimento de cestas básicas à população miserável, pagamento de subvenções e auxílios em espécie para esta finalidade, criação de programas como os "restaurantes populares", em que as refeições são fornecidas gratuitamente ou por preços próximos a zero etc. Os poderes públicos têm diversas possibilidades de atuação nessa seara, que podem ser inclusive combinadas. Eles devem se valer da criatividade e do experimentalismo democrático para testar soluções, descartando as que se revelarem pouco eficientes e aprimorando as que puderem ser melhoradas. Ao desenhar as medidas voltadas à garantia do 
mínimo existencial, as instâncias políticas têm, certamente, que considerar as necessidades básicas das pessoas, mas também devem tomar em conta uma série de aspectos técnicos, além da disponibilidade dos recursos existentes, o que se liga ao nível de riqueza da sociedade.

Por isso, deve caber prima facie ao legislador a competência para a definição das prestações ligadas ao mínimo existencial - a não ser naqueles casos em que elas já estejam especificamente definidas pelo próprio texto constitucional, como na hipótese do pagamento de um salário mínimo para pessoas idosas ou portadoras de deficiência em condições de miserabilidade (art. 203, inciso V, CF). Tal afirmação se funda não apenas no princípio democrático, como também no reconhecimento de que o legislador tem, a priori, uma capacidade instituciona ${ }^{10}$ superior à do Poder Judiciário para avaliar quais políticas públicas voltadas à concretização do mínimo existencial são mais eficientes, considerando a relação entre o seu custo - não apenas no sentido econômico, mas também de geração de externalidades negativas - e o seu benefício.

Essa prioridade, como dito, é apenas prima facie. Em outras palavras, o Judiciário tem a missão de controlar os demais poderes estatais nessa seara, sendo legítima a intervenção jurisdicional voltada à garantia do mínimo existencial. Tal intervenção, todavia, nem sempre deve se dar por meio da imposição da entrega de prestações específicas. Ela pode, eventualmente, envolver técnicas mais flexíveis e dialógicas, como se verá no próximo item.

Entendo, por outro lado, que o mínimo existencial, além da sua faceta social, possui também um componente ecológico (SARLET; FENSTERSEIFER, 2010, p. 11-38), que envolve a garantia de condições ambientais sem as quais não há vida digna. Isto porque, independentemente do debate sobre a existência de possíveis sujeitos não humanos dos direitos fundamentais e da própria dignidade (REGAN, 2004; NUSSBAUM, 2006, p. 325-407; LOURENÇO, 2008; MOLINARO, 2008) - como os animais ou a Terra (a Pachamama do constitucionalismo da Bolívia e do Equador, ou a Gaia dos ambientalistas da deep Ecology) -, é certo que a deterioração do meio ambiente pode gerar gravíssimos impactos sobre a qualidade de vida das pessoas, das presentes e futuras gerações, chegando às vezes ao ponto de comprometer o seu direito à vida digna. Esses impactos negativos, aliás, tendem a se concentrar nos segmentos mais carentes da sociedade, exatamente os mesmos que sofrem as privações sociais mais sérias que caracterizam as violações "clássicas" ao mínimo existencial. A proteção ao mínimo existencial ecológico ou ambiental deve se preocupar não só com as lesões presentes ao meio ambiente e seu impacto sobre a vida das pessoas, como também com os riscos ambientais que se projetam para o futuro, sobretudo no cenário de um desenvolvimento tecnológico, por vezes imprudente, que exacerba estes riscos, colocando em jogo 
a vida de populações inteiras e até mesmo a própria sobrevivência da humanidade (DANOWSKI; CASTRO, 2014).

O direito ao mínimo existencial apresenta tanto uma dimensão prestacional como uma faceta negativa (TORRES, 2009, p. 37-38; SARLET; MARINONI; MITIDIERO, 2015, p. 588). A dimensão negativa do mínimo existencial protege as condições materiais básicas de vida de intervenções restritivas provenientes do Estado, e mesmo de particulares - haja vista a eficácia horizontal do referido direito fundamental. Ela fundamenta, por exemplo, uma imunidade tributária implícita: o Estado não pode privar a pessoa, pela via da tributação, dos bens e recursos indispensáveis para que tenha uma vida digna. É certo que, até para financiar as suas atividades voltadas à satisfação dos direitos fundamentais, o Estado tem de arrecadar tributos. Porém, um dos mais importantes limites ético-jurídicos para a sua atividade fiscal é a necessidade de não subtrair das pessoas aqueles recursos sem os quais elas não conseguem subsistir com dignidade.

Seguindo aparentemente a mesma trilha, o STJ empregou o mínimo existencial para reconhecer a não incidência de imposto de renda sobre os valores percebidos em razão de adesão do contribuinte a programa de demissão voluntária (BRASIL, Superior Tribunal de Justiça, 2009). Penso, porém, que, independentemente do juízo que se faça a propósito da incidência ou não do imposto na hipótese, não foi adequada a justificativa baseada no mínimo existencial, pois os valores, muitas vezes expressivos, recebidos por ocasião da adesão a esses planos não guardam correlação necessária com as condições materiais indispensáveis para uma vida digna. Um uso mais apropriado do mínimo existencial no campo tributário ocorreu em decisão do Tribunal Constitucional colombiano, que afastou a incidência de imposto indireto - o IVA - sobre produtos da cesta básica, a partir da consideração dos efeitos concretos que aquela tributação teria sobre as condições básicas de vida da população carente do país (COLÔMBIA, Corte Constitucional, 2003). Na referida decisão, a Corte Constitucional da Colômbia consignou:

(...) em relação à dimensão negativa, o direito fundamental ao mínimo vital se constitui em um limite ou cota inferior que não pode ser violado pelo Estado, em matéria de disposição dos recursos materiais de que a pessoa necessita para levar uma vida digna (...).

O Estado não pode, ao exercer o seu poder de tributar, ignorar se está criando tributos que de modo indiscutível e manifesto impliquem violação ao limite inferior constitucionalmente estabelecido para garantir a sobrevivência digna da pessoa, dadas as políticas sociais existentes e os efeitos das mesmas. Este limitador se tem expressado tradicionalmente na proibição de impostos confiscatórios (art. 34 da Constituição). Mas também é especialmente relevante para o caso de um direito ao mínimo vital, em particular 0 das pessoas que contém apenas com o indispensável para sobreviver (art. 13 da Constituição) (COLÔMBIA, Corte Constitucional, 2003). 
A dimensão negativa do mínimo existencial também lastreia institutos que visam a proteger a renda e o patrimônio mínimo das pessoas, ligados à vida digna, inclusive diante dos seus credores particulares. A ideia central é de que o interesse patrimonial na satisfação do crédito não deve preponderar sobre a proteção da dignidade humana do devedor. O ponto foi destacado com clareza em decisão do Tribunal Constitucional português, que afirmou a impenhorabilidade do valor das pensões, aposentadorias e benefícios sociais até o valor do salário mínimo, assentando que, no conflito entre os direitos patrimoniais do credor e o direito à subsistência do devedor, o segundo tem primazia, que deve ser assegurada pelo Poder Judiciário ${ }^{11}$ (PORTUGAL, Tribunal Constitucional, 1999). Em linha geral, concordo com a ideia, mas acho que ela comporta alguns temperamentos.

Em primeiro lugar, é preciso cuidado para não inflacionar o mínimo existencial, empregando-o em hipóteses que não tratam das condições materiais básicas para a vida digna cuidado que teve a Corte Constitucional portuguesa, mas que o Judiciário brasileiro não vem observando. Veja-se o caso do limite do desconto do crédito consignado em folha de pagamento. O legislador estabeleceu um limite máximo de desconto, que correspondia, inicialmente, a 30\% dos valores do salário, vencimentos ou pensão do devedor, e que foi posteriormente aumentado para 35\% (art. 1ํ, §1ํㅡ, Lei № 10.820/2003). A solução legislativa, que ponderou a autonomia privada do devedor com a sua proteção como consumidor, não me parece desarrazoada. Porém, não se justifica a invocação do mínimo existencial para justificar a limitação. Se um empregado receber, por exemplo, um salário líquido de vinte mil reais, um desconto de 50\%, que the assegure uma sobra de dez mil reais por mês, passará longe da garantia das condições básicas de vida. A limitação a 30 ou 35\% de desconto decorre, portanto, de válida decisão legislativa, mas não da proteção ao mínimo existencial, subtraída do alcance das maiorias políticas. Na mesma linha, parece-me forçada a ligação, traçada pelo STJ, entre a garantia do mínimo existencial e a impenhorabilidade de valores de até 40 salários mínimos mantidas em cadernetas de poupança (BRASIL, Superior Tribunal de Justiça, 2012), prevista no art. 649, inciso X, do CPC - valor que a imensa maioria dos brasileiros, mesmo da classe média, não possui em suas economias.

É preciso recordar, ademais, que a impenhorabilidade de certos bens frustra a possibilidade de satisfação de créditos que também podem ser essenciais para a garantia das condições básicas de vida do credor. E, mesmo quando isso não ocorre, a garantia do efetivo pagamento das dívidas é relevante para o adequado funcionamento da economia, cujas crises tendem a afetar sobretudo os mais pobres. Por isso, discursos muito ampliativos dessa dimensão 
negativa do mínimo existencial, ainda que aparentemente progressistas, podem, ao final, prejudicar exatamente os mais necessitados.

Assim, considero acertada a orientação do STJ de estabelecer limite jurisprudencial para a impenhorabilidade das verbas salariais, prevista no art. 649, IV, do CPC (no novo CPC, este limite foi fixado em valor correspondente a 50 salários mínimos - art. 833, §2º). O STJ, além de assentar que os valores impenhoráveis são apenas os correspondentes ao último salário, não abrangendo os montantes pretéritos que tenham sido economizados pelo devedor, fixou dito limite na importância correspondente ao valor dos subsídios de Ministro do STF - o que me parece até excessivo (BRASIL, Superior Tribunal de Justiça, 2014). Na mesma linha, concordo com a posição adotada, por maioria, pelo STF, de não invalidar a exceção à impenhorabilidade do imóvel bem de família no caso do fiador de contrato de locação, que fora postulada perante a Corte com base na tutela do direito fundamental à moradia (BRASIL, Supremo Tribunal Federal, 2006). Com efeito, é muito provável que o afastamento dessa escolha legislativa diminuísse a oferta de imóveis para aluguel ou aumentasse o custo da locação, o que prejudicaria o direito à moradia dos que não possuem casa própria, em geral, mais necessitados do que os fiadores, que se beneficiariam com a medida. De todo modo, entendo que o legislador, pelas suas capacidades institucionais, detém melhores condições para examinar tal problema sob um ângulo sistêmico do que o Poder Judiciário, razão pela qual as suas escolhas nessa área merecem uma certa deferência judicial.

A dimensão negativa do mínimo existencial também pode ser invocada em inúmeros outros contextos e situações que não terei como explorar aqui, e que suscitam diferentes e complexas controvérsias: e.g., na defesa da posse utilizada para moradia de pessoas sem teto, em litígio contra proprietários públicos ou privados; na proteção contra cassação de benefícios previdenciários ou assistenciais por motivos insuficientes; na vedação ao corte de serviços públicos essenciais em razão do não pagamento da tarifa, quando o usuário deixa de quitá-la pela falta de recursos.

Em síntese, sempre que uma intervenção do Estado ou de um particular comprometer as condições materiais básicas para a vida digna de uma pessoa, entra em jogo a dimensão negativa do direito ao mínimo existencial. Isso, porém, não significa que o mínimo existencial prevaleça sempre no confronto com os direitos ou interesses contrapostos. Sustento que a dignidade da pessoa humana não é absoluta e também pode ser ponderada com outros princípios constitucionais, assumindo, contudo, um peso muito elevado nesse sopesamento. Tal raciocínio, em minha opinião, também se aplica ao mínimo existencial. 


\section{A PROTEÇÃO JUDICIAL AO MÍNIMO EXISTENCIAL}

Como se viu acima, o mínimo existencial abrange tanto uma dimensão defensiva como uma faceta prestacional. É sobretudo a última que tem provocado debates acesos relacionados à sua proteção judicial, que se imbrica com a discussão acerca da justiciabilidade dos direitos sociais.

No Brasil, já se superou a visão, que ainda prevalece em muitos países (LANGFORD, 2008, TUSHNET, 2008; SARLET, 2003) no sentido de que os direitos prestacionais não seriam judicialmente exigíveis. Pode-se falar que a cultura jurídica brasileira, especialmente nos últimos quinze anos, "leva a sério" os direitos sociais. O reconhecimento da proteção judicial desses direitos envolveu a superação da ideia, que prevaleceu entre nós por muito tempo, de que eles seriam tutelados por "normas programáticas", que não gerariam direitos subjetivos positivos (BRASIL, Superior Tribunal de Justiça, 1996). Passou-se a reconhecer que também os direitos sociais desfrutam da aplicabilidade imediata, prevista no art. 5으, §1ํㅡ, da Constituição (SARLET, 2009).

A doutrina dominante e a jurisprudência brasileira contemporânea enfatizam que a vagueza com que muitos desses direitos estão consagrados não impede a sua concretização judicial, como também não é obstáculo para a garantia jurisdicional de diversos direitos individuais igualmente vagos - igualdade, privacidade, liberdade de expressão etc. Na mesma linha, também se reconhece que o fato de os direitos sociais envolverem custos tampouco impede a sua proteção judicial, inclusive porque os direitos individuais e políticos, cuja tutela jurisdicional se afigura inquestionável, também dependem de recursos (SUNSTEIN; HOLMES, 1999). Afinal, para que se possa votar, é necessário que ocorram eleições, cuja realização envolve gastos expressivos; para proteger a propriedade, é preciso contar com a polícia e com o aparato judiciário, que demandam recursos etc. E nos últimos tempos, em que o Direito Constitucional brasileiro deu uma guinada pós-positivista, aproximando-se da filosofia política e moral, outro argumento importante que vem sendo frequentemente ventilado em favor da proteção jurisdicional dos direitos sociais é o de que a sua garantia é um imperativo de justiça, que não pode ser deixado ao sabor das escolhas políticas ou tecnocráticas das autoridades.

Nada obstante, o reconhecimento da possibilidade de tutela jurisdicional dos direitos sociais prestacionais não afastou três importantes críticas, que, no país, vêm sendo endereçadas menos à possibilidade dessa proteção, e mais à forma, nem sempre racional, como ela vem ocorrendo. São elas: (a) a crítica democrática, de que competiria primariamente ao legislador e ao 
governo, eleitos e responsivos perante a população, a prerrogativa de definição das prioridades sobre os gastos públicos, e não ao Judiciário; (b) a crítica sobre a eficiência, no sentido de que os juízes não teriam capacidade técnica para decidir na área, que envolve políticas públicas complexas, e de que o processo judicial, pelas suas limitações, não seria o ambiente adequado para intervenções nessa seara, de modo que as decisões jurisdicionais, ainda quando muito bem intencionadas, podem prejudicar, ao invés de promover, a efetivação dos direitos sociais; (c) e a crítica sobre a equidade, que sustenta que, pela assimetria no acesso à justiça em desfavor dos pobres, a proteção jurisdicional dos direitos sociais resultaria na canalização de recursos escassos para o atendimento de demandas da classe média, agravando a injustiça social ao invés de minorála.

Apesar dessas críticas, existe atualmente no Brasil certo consenso no sentido da possibilidade de proteção judicial do mínimo existencial. Porém, algumas controvérsias importantes subsistem na matéria. Em primeiro lugar, indaga-se se essa proteção é ou não absoluta, ou seja, se ela está ou não sujeita à "reserva do possível". Em segundo lugar, debate-se sobre se o mínimo existencial atua também como limite máximo para a sindicabilidade dos direitos prestacionais fundamentada na Constituição, ou se é possível a concessão de prestações não previstas em lei que excedam ao mínimo. Esses dois temas vêm sendo bastante debatidos pela doutrina nacional (SARLET; TIMM, 2008). Nesse momento, além desses temas, quero também abordar um terceiro, que não é tão discutido, que diz respeito à possibilidade do emprego de técnicas mais flexíveis, baseadas no diálogo institucional, para a proteção judicial do mínimo existencial (TUSHNET, 2008; SOUZA, 2013).

\section{Mínimo existencial, direitos sociais e reserva do possível}

A garantia dos direitos fundamentais depende de recursos escassos, o que também vale para a proteção do mínimo existencial. A escassez obriga o Estado, em alguns casos, a se confrontar com verdadeiras "escolhas trágicas" (CALABRESI; BOBBIT, 1978), pois, diante da limitação de recursos para atender a múltiplas demandas, ele é forçado a eleger prioridades dentre diversas necessidades e exigências legítimas. As escolhas alocativas acabam sendo também desalocativas, pois subtraem "fatias do bolo" dos recursos existentes, mesmo quando isso não seja explicitado. Para lidar com esse fenômeno econômico, elaborou-se o conceito da "reserva do possível". 
A expressão "reserva do possível" (Vorbehalt des Möglichen) foi difundida a partir de célebre decisão do Tribunal Constitucional alemão, proferida em 1972, em caso conhecido como Numerus Clausus (ALEMANHA, Tribunal Constitucional, 1972), que tratou da validade da limitação do número de vagas em universidades públicas, tendo em vista a pretensão de ingresso de um número maior de candidatos. Não há, na Constituição alemã, a garantia do direito à educação, mas o Tribunal Constitucional entendeu que a liberdade profissional demandava, em alguma medida, o direito de acesso ao ensino superior. Todavia, frisou que tal direito "se encontra sob a reserva do possível, no sentido de estabelecer o que o indivíduo pode razoavelmente exigir da sociedade". Segundo a Corte germânica, tal decisão cabe primariamente ao legislador, que deve "atender, na administração do seu orçamento, também a outros interesses da coletividade". Trata-se de conceito também empregado em outras ordens jurídicas (CANOTILHO, 2004, p. 108), até porque decorre de uma realidade econômica - a escassez - que é universal.

No Brasil, a jurisprudência alude com frequência à ideia de reserva de possível desde que o Min. Celso de Mello proferiu a já mencionada decisão monocrática na ADPF 45, que se referiu ao instituto, embora relativizando, já de partida, a sua relevância (BRASIL, Supremo Tribunal Federal, 2004). A maior parte dos julgados subsequentes sobre o assunto reproduz trechos dessa decisão, que passou a ser a formulação canônica sobre a matéria na jurisprudência brasileira. Recentemente, o STF proferiu importante decisão assentando que a reserva do possível não pode ser invocada como obstáculo para imposição de obrigações de fazer pelo Poder Judiciário, concernentes a obras emergenciais em estabelecimentos prisionais, voltadas à garantia da dignidade humana dos presos (BRASIL, Supremo Tribunal Federal, 2015).

A reserva do possível pode ser desdobrada em três componentes: o componente fático, que diz respeito à efetiva existência de recursos necessários à satisfação do direito prestacional em jogo; o componente jurídico, que se liga à existência de autorização legal - especialmente na lei orçamentária - para a realização da despesa exigida pela efetivação do direito; e a razoabilidade da prestação, considerando os recursos existentes e todos os demais encargos que pesam sobre o Estado (SARLET; FIGUEIREDO, 2008).

Começando pelo mais simples, entendo que o componente jurídico é realmente inoponível às prestações compreendidas pelo mínimo existencial. Não se trata de negar a importância do princípio da legalidade orçamentária, vital para democratizar e racionalizar a atividade financeira do Estado (TORRES, 2000, p. 243-277; MENDONÇA, 2010). Contudo, por todas as razões já expostas, a garantia do mínimo existencial, que é pressuposto da democracia, não pode ficar à 
mercê das decisões do legislador infraconstitucional. Assim, o fato de inexistir previsão no orçamento para a realização de despesa necessária à satisfação do mínimo existencial não deve obstar a sua concessão em sede judicial. Este é o posicionamento majoritário na doutrina (TORRES, 2009, p. 40; SARLET; FIGUEIREDO, 2008, p. 34-35) que é acolhido também pela nossa jurisprudência (BRASIL, Supremo Tribunal Federal, 2000).

O componente da razoabilidade da reserva do possível tampouco me parece oponível ao mínimo existencial, sobretudo se este for definido de forma prudente, compatível com o imperativo de universalização do mínimo, anteriormente referido. Afinal, não se pode negar a razoabilidade da pretensão de uma pessoa de ter acesso às condições materiais básicas para uma vida digna. Se a pretensão não for razoável, é simplesmente porque ela não está inserida no mínimo existencial.

A questão, contudo, é mais complexa em relação ao componente fático da reserva do possível, pois aqui o obstáculo não é jurídico ou ético, mas decorre da realidade econômica. Assinale-se, em primeiro lugar, que a reserva do possível fática não pode ser vista tomando em conta apenas a pretensão individual demandada em juízo. Fosse esse o caso, o conceito seria praticamente irrelevante, pois é altamente implausível que o atendimento ao direito de uma única pessoa tenha algum impacto significativo no universo dos recursos disponíveis de um ente público. É uma exigência inexorável do princípio da igualdade que o Estado só conceda a uma pessoa aquilo que tenha condições de dar às outras que estiverem em idêntica situação. Por isso, a reserva do possível fática deve ser compreendida como a capacidade financeira do Estado de arcar com a universalização da prestação material postulada, para todas as pessoas que estiverem nas mesmas condições daquele que a requereu.

A doutrina majoritária afirma que a reserva do possível fática tampouco é oponível ao mínimo existencial (SARLET; FIGUEIREDO, 2008, p. 37). Esta posição vem sendo externada inclusive pelo STF (BRASIL, Supremo Tribunal Federal, 2011). Considero, todavia, que a tese, conquanto sedutora, não procede. Afinal, a relevância de uma pretensão sob o prisma jurídico ou moral não tem o condão de revogar a lei econômica da escassez. A escassez é um fato e, se não existirem na sociedade os recursos necessários para a garantia de prestações ligadas ao mínimo existencial, simplesmente não haverá alquimia jurídica que possa contornar o limite, que não é imposto pelo Direito, mas pela própria realidade (ROSE-ACKERMAN, 2004, p. 243). E, como advertiu há muito tempo o jurista francês Georges Ripert, "quando o Direito ignora a realidade, a realidade se vinga ignorando o Direito". 
Note-se, porém, que a existência de recursos na sociedade não equivale à sua presença nos cofres estatais em um dado momento. É que o Estado não pode, por exemplo, cortar ou abster-se de cobrar tributos que onerem os ricos quando isso o prive dos recursos que seriam essenciais para a garantia das condições básicas de vida para os miseráveis. No limite, para assegurar a proteção ao mínimo existencial, o Judiciário pode até reconhecer a obrigação estatal de alterar a sua política fiscal com vistas à obtenção de recursos adicionais (TORRES, 1992, p. 2949). A possibilidade, porém, tem de ser vista com muita cautela, como ultima ratio, não só por conta do princípio da legalidade tributária - e dos valores de segurança jurídica e democracia que o lastreiam -, como também em razão dos déficits de capacidade institucional do Poder Judiciário para aquilatar os efeitos econômicos sistêmicos de alterações na legislação tributária.

De todo modo, ainda que não se reconheça a absoluta oponibilidade do mínimo existencial à reserva do possível fática, pode-se afirmar pelo menos a forte prioridade das prestações concernentes ao mínimo existencial em relação a todas as demais despesas estatais, suscetível inclusive de controle judicial. O Estado, nessa perspectiva, não poderá denegar prestações voltadas ao atendimento de necessidades básicas das pessoas, sob a invocação de ausência de recursos, se estiver realizando despesas supérfluas - obras de embelezamento, publicidade, promoção de festas e eventos etc. Daí porque se pode dizer que, pelo menos em países não miseráveis, como o Brasil, o mínimo existencial deve ser quase sempre assegurado em sede judicial, quando não o seja na esfera da política majoritária.

Existem, todavia, hipóteses em que isso não é possível. Um bom exemplo diz respeito ao salário mínimo, que, por definição constitucional, se volta à garantia "das necessidades vitais básicas" do trabalhador e da sua família - ou seja, do mínimo existencial. De acordo com o art. 7ํㅡ, IV, da Constituição, o salário mínimo deve ser suficiente para os gastos familiares com "moradia, alimentação, educação, saúde, lazer, higiene, transporte e previdência social". Mesmo considerando a gratuidade da saúde e da educação públicas, parece evidente que o salário mínimo vigente no país não satisfaz a exigência constitucional, especialmente nos grandes centros urbanos, em que vive a maior parte dos brasileiros. Nesse quadro, seria possível para o Judiciário impor aumento imediato no salário mínimo até um montante suficiente para a satisfação do mínimo existencial - o que talvez equivalesse a algo como dobrá-lo? Teria a economia brasileira como suportar o impacto de uma majoração imediata dessa magnitude? Será que decisão dessa natureza não poderia "quebrar" a Previdência Social e muitas empresas privadas, além de aumentar o desemprego e a informalidade no mercado de trabalho? E teria o Poder Judiciário a capacidade 
institucional necessária para tomar essa decisão, que certamente acarretaria um verdadeiro terremoto macroeconômico no país?

No passado, o STF chegou a reconhecer a inconstitucionalidade por omissão parcial do legislador, pela fixação do salário mínimo em valor insuficiente (BRASIL, Supremo Tribunal Federal, 2004). A Corte, porém, absteve-se de tomar qualquer medida adicional, além da mera notificação do Congresso, até em razão do posicionamento então vigente sobre o seu papel estrito de legislador negativo no controle das omissões constitucionais. Na atualidade, contudo, diante da nova orientação jurisprudencial a propósito do mandado de injunção, seria até possível para a Corte, sob o prisma estritamente processual, proferir decisão aditiva, fixando um novo valor para o salário mínimo que fosse compatível com o art. 7o, IV, da Constituição e com a garantia do mínimo existencial, tendo em vista a inequívoca existência da inconstitucionalidade por omissão parcial na matéria.

Estou convicto, porém, que uma decisão que ajustasse imediatamente o salário mínimo às exigências do mínimo existencial não seria factível na prática: não haveria como cumpri-la sem levar o país à bancarrota. E os efeitos práticos da tentativa de cumprimento tenderiam a ser desastrosos, especialmente para os mais pobres. Enfim, um excesso ativista nessa área, ainda que muito bem-intencionado, poderia, ao final, destruir a economia nacional e, nestas crises, as maiores vítimas costumam ser exatamente os segmentos sociais mais vulneráveis.

Daí porque, embora reconheça uma forte prioridade estatal na realização dos gastos atinentes ao mínimo existencial, não concordo com a tese de que, em relação a ele, seja absolutamente imponível a reserva do possível. De todo modo, estando em jogo o mínimo existencial, justifica-se um escrutínio muito mais rigoroso do Poder Judiciário sobre as escolhas alocativas e desalocativas dos poderes públicos, para que se verifique a sua compatibilidade com prioridades que derivam da própria Constituição.

Por outro lado, não me parece correta a tese de que o mínimo existencial seja um teto intransponível para a proteção dos direitos sociais fundada diretamente na Constituição (TORRES, 2009, p. 130-132; BARCELLOS, 2002, p. 233-234), por várias razões. Em primeiro lugar, porque o texto constitucional é expresso ao positivar, por meio de regras claras, direitos sociais que vão além do mínimo - e.g., benefícios previdenciários para servidores públicos e gratuidade do ensino público, inclusive no nível superior e pós-graduação. Ademais, não me parece adequado afirmar, por um lado, que em relação aos direitos individuais se deve perseguir a máxima efetividade, mas em relação aos direitos sociais prestacionais não se pode ultrapassar o mínimo. A adoção dessa 
lógica de "dois pesos e duas medidas" não é compatível com a nossa ordem constitucional, que não contempla hierarquias ou preferências entre as diferentes "gerações" de direitos. A extensão da proteção jurisdicional dos direitos sociais prestacionais depende também de outros fatores, como a maneira como eles estão positivados na Constituição e a intensidade da tutela, em cada caso, de princípios e bens jurídicos concorrentes.

Nesse modelo, o mínimo existencial constitui um elemento relevante na adjudicação dos direitos sociais, mas não representa algum tipo de algoritmo mágico, cujo manejo tenha o condão de resolver todos os problemas ligados à sua proteção jurisdicional.

\section{Proteção judicial do mínimo existencial e técnicas processuais dialógicas e flexíveis}

Muito embora o mínimo existencial seja juridicamente exigível, nem sempre a forma mais adequada de assegurá-lo em juízo consiste na tutela jurisdicional tradicional, com a concessão da prestação reivindicada. Especialmente nos casos em que a lesão ao mínimo existencial decorra de problemas estruturais, cujo enfrentamento demande a correção ou formulação de políticas públicas complexas, a atuação solitária do Poder Judiciário pode não ser a solução ideal (GARGARELLA, 2011, p. 232-245). Dois fatores importantes recomendam que, especialmente em casos dessa natureza, se dê preferência ao emprego de técnicas processuais mais flexíveis (SABEL; SIMON, 2004, p. 1015-1101; CAMPOS, 2015) permeadas pelo diálogo interinstitucional (MENDES, 2011; BRANDÃO, 2011): (a) a existência, já destacada acima, de um espaço de livre conformação legislativa atinente à definição das políticas públicas voltadas à concretização do mínimo existencial; e (b) o reconhecimento de que a atuação judicial concertada com outros poderes e órgãos estatais pode gerar resultados mais eficientes para a garantia do mínimo existencial do que a adoção da postura mais tradicional, tendo em vista, especialmente, os déficits de capacidade institucional do Poder Judiciário para definição e controle de políticas públicas em comparação com as demais agências estatais.

O uso de técnicas dessa natureza para garantia do mínimo existencial ocorreu no conhecido caso Grootboom (ÁFRICA DO SUL, Corte Constitucional, 2000), julgado pela Corte Constitucional sul-africana em 2000. Na hipótese, discutia-se o direito de centenas de indivíduos miseráveis, que estavam vivendo em condições precaríssimas, em barracas de plástico, depois de terem sido despejados da área particular, e que reivindicavam do Estado o acesso à moradia adequada. A Corte Constitucional entendeu que não seria possível assegurar imediatamente o 
direito à moradia a cada um. Porém, o Tribunal não se esquivou de controlar as políticas públicas habitacionais promovidas pelo Estado e concluiu que as então existentes falhavam gravemente por não incluírem medidas emergenciais, focadas nas pessoas em situação de carência desesperadora (desperate need). Diante disso, determinou a reformulação da política estatal sobre moradia pelo governo para que contemplasse medidas de alívio imediato para pessoas miseráveis, sem, no entanto, precisar quais providências deveriam ser adotadas. Para permitir uma fiscalização mais adequada da execução da sua decisão, a Corte atribuiu a um órgão técnico independente - a Human Rights Commission -, de reconhecida expertise e prestígio na África do Sul em matéria de direitos fundamentais, a tarefa de supervisionar a elaboração e implementação do novo programa, reportando-se ao tribunal. Esse modelo sul-africano foi muito elogiado pela doutrina comparatista (ABRAMOVICH; COURTIS, 2005, p. 160-168; SUNSTEIN, 2001) por ensejar a proteção de direitos sociais por meio de técnica do diálogo institucional, que minimiza o problema do déficit de expertise do Poder Judiciário para lidar com políticas públicas.

Na Alemanha, o equacionamento do conhecido caso Hartz IV (ALEMANHA, Tribunal Constitucional Federal, 2010) também se pautou pelo diálogo institucional. Discutiu-se, naquele julgamento, a constitucionalidade de lei que tratava de benefício de assistência social, percebido à época por cerca de 6,7 milhões de pessoas (EGIDY, 2011). A Corte reconheceu que não era possível extrair diretamente da Lei Fundamental um valor predeterminado para o benefício social em questão, mas considerou que o procedimento para cálculo da referida importância deveria se pautar por determinados elementos, que o legislador não seguira, como, por exemplo, certas considerações de natureza estatística. Assim, manteve provisoriamente a lei questionada, mas determinou ao legislador que a reformasse e que estipulasse um novo valor para o benefício a partir de procedimento que deveria necessariamente sopesar uma série de variáveis que indicou. A Corte Constitucional, portanto, definiu marcos para o cálculo do benefício em atenção à proteção do mínimo existencial, mas preservou um espaço razoável para a valoração legislativa na matéria.

Outro exemplo riquíssimo de diálogo institucional na proteção de direitos ligados ao mínimo existencial vem da jurisdição constitucional colombiana e se liga ao reconhecimento do chamado estado de coisas inconstitucional (GARAVITO, 2010). Essa técnica, que não está expressamente prevista na Constituição ou em qualquer outro instrumento normativo permite à Corte Constitucional atuar visando à superação de violações graves e massivas de direitos fundamentais (ARIZA, 2013, 129). Para reconhecer o estado de coisas inconstitucional, a Corte Constitucional da Colômbia exige que estejam presentes as seguintes condições: (i) vulneração 
massiva e generalizada de direitos fundamentais de um número significativo de pessoas; (ii) prolongada omissão das autoridades no cumprimento de suas obrigações para garantia e promoção dos direitos; (iii) a necessidade, para a superação das violações de direitos, de adoção de medidas complexas por uma pluralidade de órgãos, envolvendo mudanças estruturais, que podem depender da alocação de recursos públicos, correção de políticas públicas existentes ou formulação de novas políticas, dentre outras medidas; e (iv) potencialidade de congestionamento da justiça se todos os que tiverem os seus direitos violados acorrerem individualmente ao Poder Judiciário (CAMPOS, 2015, p. 134-138).

Tal técnica já foi utilizada para diversos casos ligados ao mínimo existencial, como o concernente ao calamitoso estado do sistema carcerário colombiano (COLÔMBIA, Corte Constitucional, 1998), o não pagamento generalizado de pensões e aposentadorias numa região administrativa do país (Departamento del Chocó) (COLÔMBIA, Corte Constitucional, 2000), e a dramática situação da população deslocada internamente por força da guerrilha que o país vivenciou - os chamados desplazados (COLÔMBIA, Corte Constitucional, 2014). Para equacionar situações que caracterizam o estado de coisas inconstitucional, o Tribunal colombiano normalmente determina aos entes estatais competentes que formulem planos de ação para resolução do problema, examina e aprova estes planos e depois monitora a sua implementação, em processo público, com a participação da sociedade civil (HUAROTO, 2013).

O uso dessas técnicas dialógicas na proteção de direitos sociais não é de todo estranha à jurisdição brasileira. Em recente decisão proferida em ação civil pública, em que se discutia a falta de vagas em creches no Município de São Paulo - tema também afeto ao mínimo existencial - o Tribunal de Justiça do Estado de São Paulo obrigou o ente federativo a criar, no mínimo, 150.000 vagas novas até 2016 e a incluir em seu orçamento recursos suficientes para tal providência (SÃO PAULO, Tribunal de Justiça, 2013). Mas, diante da falta de expertise da Corte para definir o modo de cumprimento da obrigação, condenou também o referido município a formular, em 60 dias, um plano para ampliação de vagas e construção de novas unidades de educação infantil, e a apresentar semestralmente relatórios sobre as medidas adotadas em cumprimento do plano. $\mathrm{O}$ Tribunal determinou, ainda, que a execução do julgado fosse monitorada com o auxílio da Coordenadoria de Infância e Juventude daquela corte, em articulação com a sociedade civil, a Defensoria Pública e o Ministério Público. Esse tipo de solução está sendo postulada na ADPF 347, em curso no Supremo Tribunal Federal, em que se busca a construção de soluções interinstitucionais para o quadro dramático do sistema prisional brasileiro, que certamente envolve 
múltiplas violações ao mínimo existencial da população encarcerada. Nossa Suprema Corte, ao apreciar o pedido de medida cautelar, reconheceu, por unanimidade, a existência da categoria do estado de coisas inconstitucional na ordem jurídica brasileira (BRASIL, Supremo Tribunal Federal, 2015).

Essas técnicas decisórias podem ser empregadas no Brasil tanto no âmbito de ações coletivas como no contexto da jurisdição constitucional concentrada. Elas viabilizam intervenções jurisdicionais mais inteligentes, inclusive para o enfrentamento de lesões sistemáticas ao mínimo existencial, que frequentemente ocorrem em países subdesenvolvidos e que não teriam como ser equacionadas de forma satisfatória pelo Poder Judiciário. Veja-se, no Brasil contemporâneo, as questões atinentes à péssima qualidade do ensino público - em que estudantes pobres muitas vezes concluem o nível médio e permanecem analfabetos funcionais, incapazes de escrever textos inteligíveis e de compreender o que leem -, bem como a deficiência das políticas públicas de universalização do saneamento básico, que "mata" anualmente milhares de pessoas carentes. $\mathrm{O}$ mínimo existencial está diretamente implicado nesses casos e, nada obstante, não parece que o Judiciário tenha a menor condição de equacioná-los sozinho.

É que a importância dos direitos envolvidos, sob o ângulo jurídico ou moral, não é suficiente para eliminar a dificuldade prática que o Judiciário enfrenta para lidar com eles de modo eficaz. A variável institucional não pode ser ignorada no plano da efetivação dos direitos, pois, do contrário, as intervenções jurisdicionais, mais do que ineficazes, podem se revelar até contraproducentes, sob a perspectiva dos próprios objetivos que visam a promover.

Nesse cenário, o recurso a técnicas jurisdicionais flexíveis e dialógicas constitui alternativa importante, preferível tanto à omissão judicial quanto a um ativismo de resultados duvidosos. O Judiciário pode destravar bloqueios políticos e sociais existentes no equacionamento de certos temas, conferindo visibilidade a questões importantes ligadas ao mínimo existencial e forçando os demais poderes a agir, sem, no entanto, apresentar soluções prontas para problemas altamente complexos, que muitas vezes ele não teria condições de elaborar a contento.

\section{CONCLUSÃO}

O princípio da dignidade da pessoa humana compreende o direito de acesso às necessidades materiais básicas de vida - o direito ao mínimo existencial -, que, na nossa ordem constitucional, constitui um piso para a justiça social, mas não um teto para a atuação estatal voltada à promoção da igualdade material e dos direitos sociais. A garantia do mínimo existencial é 
pressuposto para o pleno exercício das liberdades civis e da democracia, mas se justifica por razões autônomas, que independem desses objetivos.

O Poder Judiciário tem plena legitimidade para atuar nessa seara, garantindo o mínimo existencial mesmo quando isso envolva eventual interferência nas escolhas alocativas e desalocativas adotadas pelo Estado, que não se coadunem com a prioridade constitucional de atendimento às necessidades básicas das pessoas. Mas os déficits de capacidade institucional do Judiciário não permitem que ele assuma qualquer tipo de protagonismo na matéria. Esse déficit, aliado ao princípio democrático, recomenda que, quando for necessário criar ou alterar políticas públicas para garantir o mínimo existencial, a atuação jurisdicional se dê preferencialmente por meio de técnicas flexíveis, baseadas no diálogo interinstitucional.

O mínimo existencial deve ser garantido pelo Estado e pela sociedade para todos, mas o foco prioritário tem de recair sobre os segmentos mais vulneráveis da população. A categoria, erigida para proteção de grupos subalternos, não pode se converter em mais um belo rótulo para a proteção dos interesses da classe média e da elite.

\section{NOTAS}

1. Tribunal Constitucional Federal da Alemanha. BVerfGE 40, 121 (1975). Nessa importante decisão, a Corte alemã assentou: "Certamente a assistência aos desamparados integra as obrigações de um Estado Social (...). Isto inclui, necessariamente, a assistência social aos concidadãos, que, em virtude de sua precária condição física e mental, se encontram limitados nas suas atividades sociais, não apresentando condições de prover a própria subsistência. A comunidade estatal deve assegurar-lhes pelo menos as condições mínimas para uma existência digna e envidar os esforços necessários para integrar estas pessoas na comunidade, fomentando o seu acompanhamento e apoio na família ou por terceiros, bem como criando as indispensáveis instituições assistenciais" (colhi a tradução em SARLET, Ingo Wolfgang. Direitos fundamentais sociais, mínimo existencial e direito privado: breves notas sobre alguns aspectos da possível eficácia dos direitos sociais nas relações entre particulares. In: SARMENTO, Daniel; GALDINO, Flávio (orgs.). Direitos fundamentais: estudos em homenagem ao Professor Ricardo Lobo Torres. Rio de Janeiro: Renovar, 2006, p. 565).

2. Em Portugal, a decisão paradigmática sobre o mínimo existencial foi a proferida pelo Tribunal Constitucional no Acórdão 509/02, que afirmou a inconstitucionalidade de norma 
que retirava o acesso ao chamado "rendimento social de inserção" das pessoas entre 18 e 25 anos de idade. Nesse julgado, proclamou-se que "o princípio do respeito da dignidade humana (...) implica o reconhecimento do direito ou da garantia a um mínimo de subsistência digna". Veja-se o comentário da referida decisão em NOVAIS, Jorge Reis. Os princípios constitucionais estruturantes da República Portuguesa. Coimbra: Coimbra Editora, 2004, p. 52-100.

3. A Constituição da Índia de 1950 prevê direitos sociais e econômicos como "princípios diretivos da política estatal", mas veda a sua garantia jurisdicional. A proibição vem sendo superada pela jurisprudência da Suprema Corte indiana por meio do recurso do direito à vida, que, na visão daquele tribunal, assegura também o direito à subsistência com dignidade, que equivale ao mínimo existencial. Cf. MURALIDHAR, R. India: The Expectations and Challenges of Judicial Enforcement of Social Rights. In: LANGFORD, Malcolm (Ed.). Social rights jurisprudence: emerging trends in international and comparative law. Cambridge: Cambridge University Press, 2008.

4. É curioso observar que Ronald Dworkin - o outro "gigante" do liberalismo igualitário -, apesar das suas posições progressistas no campo da justiça social e da sua teoria sobre a interpretação constitucional muito aberta aos influxos da moralidade política, sempre recusou o reconhecimento constitucional de direitos sociais, mesmo daqueles ligados à garantia do mínimo existencial. Nas palavras de Lawrence Sager, "sempre foi um tanto misteriosa a razão pela qual Dworkin, com a sua visão generosa sobre o conteúdo da Constituição, e o seu compromisso com um modelo de interpretação constitucional sempre aberto a diretrizes do mundo da justiça política, tenha se inclinado a deixar órfãos os direitos materiais" (SAGER, Lawrence. Material rights, underenforcement, and the adjudication thesis. Boston University Law Review. v. 90, 2010, p. 579). Sager concluiu que tal posição de Dworkin teria decorrido não da sua filosofia moral, mas da associação incindível que ele fazia entre direitos e adjudicação judicial, e da sua descrença na capacidade de os juízes se engajarem com proveito na tarefa de garantir os direitos sociais. Pude, aliás, presenciar e tomar parte de acalorados debates entre Dworkin e professores brasileiros a esse respeito, em evento realizado no ano de 2005, no auditório da Procuradoria do Município do Rio de Janeiro.

5. Habermas parece não atribuir o mesmo status aos direitos sociais do que aos civis e políticos em razão do seu profundo desconforto em relação ao Estado Social, que se funda 
na crença de que seu funcionamento induziria ao paternalismo e minaria as bases da autonomia pública e privada dos cidadãos (cf. ARANGO, Rodolfo. El concepto de derechos sociales fundamentales. Op. cit., p. 266-267). Veja-se, nessa linha, a crítica habermasiana ao Welfare State: "Pode-se dizer que o Welfare State paga, pela atuação estatal, o preço do status autônomo dos atores individuais. O que é concedido ao Estado em capacidade para regulação social deve aparentemente ser retirado, na forma de autonomia privada, dos indivíduos, enredados em dependências sistêmicas. (...) O Estado Social provê serviços e oportunidades de vida, pela garantia de seguridade social, saúde, moradia, renda mínima, educação, lazer, e as bases naturais da vida, garantindo a cada pessoa as condições materiais para uma existência humana dignificada. Todavia, um Estado Social com tantas tarefas tende quase inevitavelmente a impor modelos de comportamento supostamente 'normais' à sua clientela. Evidentemente, essa pressão normalizadora incide no risco de prejudicar a autonomia individual, precisamente a autonomia que se supunha que ela promovesse, ao prover as condições fáticas necessárias à igual oportunidade para exercício das liberdades negativas" (HABERMAS, Jürgen. Paradigms of law. In: ROSENFELD, Michel; ARATO, Andrew. Habermas on law and democracy: critical exchanges. Berkeley: University of California Press, 1998, p. 17).

6. Em pelo menos duas decisões, ambas da relatoria do Min. Castro Meira, o STJ aludiu en passant ao mínimo existencial de pessoas jurídicas. Tratava-se, em ambos os casos, de discussão sobre a penhora on line, em que a Corte afirmou que caberia "ao juízo da execução o conhecimento de hipóteses concretas, em que a execução se verifique extremada e altamente danosa a ponto de sonegar do devedor o mínimo existencial para a sua sobrevivência, como a paralização da atividade empresarial, no caso particular de pessoa jurídica" (o texto figura nas duas decisões). Superior Tribunal de Justiça, 2a Turma, AgRg no REsp 1217839, Rel. Min. Castro Meira, julg. 18.11.2011; e 2a Turma, AgRg no REsp 1182130, Rel. Min. Castro Meira, julg. 18.11.2010.

7. O leading case foi a Sentecia 125/94, em que se reconheceu a afronta ao mínimo existencial no ato de um filho que vendera o imóvel do seu pai, em que este habitava, sem a sua autorização e passara a dilapidar os recursos correspondentes decorrentes da venda, deixando o genitor em situação de penúria. A Corte emprega o mínimo existencial, inclusive, em casos trabalhistas, que envolvem o não pagamento de salário, na parte em que o mesmo abrange os recursos necessários à garantia da vida digna. 
8. Nessa linha, o Tribunal Constitucional alemão, no julgamento do caso Hartz IV, afirmou que o mínimo existencial compreende as condições necessárias "para a existência física e para uma mínima participação na vida social, cultural e política" (BVerfGE 125, 175 (2009)). No mesmo sentido, a Corte Constitucional da Colômbia esclareceu que o mínimo vital "incorpora um componente social que obriga o Estado a considerar a pessoa em sua plena dimensão, não só material como também espiritual, cuja subsistência não se esgota na simples sobrevivência, pelo fornecimento de alimentos, como também envolve todas as necessidades inerentes à sua condição de ser humano, inserido na família e na sociedade" (Sentencia T-011/98).

9. Como observou o Tribunal Constitucional português no Acórdão no 509/02, "o legislador goza da margem de autonomia necessária para escolher os instrumentos adequados para garantir o direito a um mínimo de existência condigna, podendo modelá-los em função das circunstâncias e dos seus critérios políticos próprios". Esse poder, de acordo com a Corte portuguesa, "é uma decorrência do princípio democrático, que supõe a possibilidade de escolhas e de opções que dê significado ao pluralismo e à alternância democráticas". Há, porém, limites para essa liberdade política, já que o pressuposto é que "as suas (do legislador) escolhas assegurem, com um mínimo de eficácia jurídica, a garantia do direito a um mínimo de existência condigna para todos os casos".

10. A consideração das capacidades institucionais é um elemento importante na interpretação da Constituição, que recomenda que se evitem posturas excessivamente otimistas em relação ao desempenho dos agentes estatais nessa área. No Brasil, a advertência é pertinente, pois há uma tendência, própria do neoconstitucionalismo, de apostar todas as fichas na proteção judicial dos direitos sociais, e o Poder Judiciário nem sempre tem condições de fazê-lo. Tratei do tema em SARMENTO, Daniel. A proteção judicial dos direito sociais: alguns parâmetros ético-jurídicos. Op. cit. Sobre o tema das capacidades institucionais no Direito, veja-se SUNSTEIN, Cass; VERMEULLE, Adrian. Interpretation and institutions. John M. Olin Law \& Economics Working Paper, n. 156, 2002. Disponível em: <http://www.law.uchicago.edu/Lawecon/index.htlm>; e VERMEULLE, Adrian. Judging under uncertainty: an institutional theory of legal interpretation. Cambridge: Harvard University Press, 2006.

11. Tribunal Constitucional de Portugal. Acórdão 318/99, Relator Conselheiro Vitor Nunes de Almeida. Consta da decisão: "Pode, assim, configurar-se um conflito entre o direito do 
credor à realização rápida do pagamento do seu crédito e o direito do devedor e pensionista da Segurança Social ou do Estado à percepção de uma pensão que Ihe garanta o mínimo de subsistência condigna com a sua dignidade de pessoa. Existindo o referido conflito, o legislador não pode deixar de garantir a tutela do valor supremo da dignidade da pessoa humana - sacrificando o direito do credor na parte que for absolutamente necessária - e que pode ir até a totalidade desse direito - por forma a não deixar que do pagamento ao credor decorra o aniquilamento da mera subsistência do devedor".

\section{REFERÊNCIAS BIBLIOGRÁFICAS}

ABRAMOVICH, Victor; COURTIS, Christian. Los derechos sociales como derechos exigibles. 2. ed. Madrid: Editorial Trotta, 2004.

ALEXY, Robert. Teoria dos direitos fundamentais. Trad. Virgílio Afonso da Silva. São Paulo: Malheiros, 2008.

ARANGO, Rodolfo; LEMAITRE, Julieta. Jurisprudencia constitucional sobre el derecho al mínimo vital. Bogotá: Ediciones Uniandes, 2002.

ARIZA, Libardo José. The economic and social rights of prisoners and constitutional court intervention in the penitentiary system in Colombia. In: MALDONADO, Daniel Bonilla (ed.). Constitutionalism of the global south. Cambridge: Cambridge University Press, 2013.

BACHOF, Otto. Der soziale Rechtsstaat in verwaltungsrechtlicher Sicht. In: Veröffentlichungen der Vereinigung der Deutschen Staatsrechtslehrer, Heft 12: Begriff und Wesen des sozialen Rechtsstaates; Die auswärtige Gewalt der Bundesrepublik. Berlin: Walter de Gruyter \& Co., 1954.

BARAK, Aharon. Human dignity: the constitutional value and the constitutional right. Cambridge: Cambridge University Press, 2015.

BARCELLOS, Ana Paula de. A eficácia jurídica dos princípios constitucionais: o princípio da dignidade da pessoa humana. Rio de Janeiro: Renovar, 2002.

BARROSO, Luís Roberto. Da falta de efetividade à judicialização excessiva: direito à saúde, fornecimento gratuito de medicamentos e parâmetros para a atuação judicial. In: SOUZA NETO, Cláudio Pereira de; SARMENTO, Daniel (orgs.). Direitos sociais: fundamentos, judicialização e direitos sociais em espécie. Rio de Janeiro: Lumen Juris, 2008

BERLIN, Isaiah. Dois conceitos de liberdade. In: Estudos sobre a humanidade. Trad. Rosaura Eichenberg. Rio de Janeiro: Companhia das Letras, 2002, p. 231.

BINENBOJM, Gustavo; CYRINO, André Rodrigues. O direito à moradia e a penhorabilidade do bem único do fiador nos contratos de locação: limites à revisão judicial de diagnósticos e prognósticos 
legislativos. In: SOUZA NETO, Cláudio Pereira de; SARMENTO, Daniel (orgs.). Direitos sociais: fundamentos, judicialização e direitos sociais em espécie. Rio de Janeiro: Lumen Juris, 2008

BLAUG, Ricardo; SCHWARZMANTEL, John. Democracy: a reader. Edinburg: Edinburg University Press, 2000.

BÖCKENFÖRDE, Ernst-Wolfgang. Los derechos fundamentales sociales en la estructura de la Constituición. In: Escritos sobre derechos fundamentales. Trad. Juan Requejo Pagés e Ignacio Villaverde Menendez. Baden-Baden: Nomos, 1993.

BONAVIDES, Paulo; ANDRADE, Paes. História Constitucional do Brasil. 3. ed. São Paulo: Paz e Terra, 1991.

BOROWSKY, Martin. La estructura de los derechos fundamentales. Trad. Carlos Bernal Pulido. Bogotá: Universidad Externado de Colombia, 2003

CALABRESI, Guido; BOBBIT, Philip. Tragic choices. New York: Norton, 1978.

CAMPOS, Carlos Alexandre de Azevedo. Da inconstitucionalidade por omissão ao estado de coisas inconstitucional. 2015. Tese (Doutorado em Direito) - Faculdade de Direito, Universidade do Estado do Rio de Janeiro, Rio de Janeiro, 2015.

CARVALHO, José Murilo de. A cidadania no Brasil: um longo caminho. 5. ed. Rio de Janeiro: Tempo Brasileiro, 2004

CITTADINO, Gisele. Pluralismo, direito e justiça distributiva: elementos de filosofia constitucional contemporânea. Rio de Janeiro: Lumen Juris, 1999

CLÈVE, Clemerson Merlin. A eficácia dos direitos fundamentais sociais. Boletim Científico da Escola Superior do Ministério Público da União. n. 8, 2003.

CRUZ, Álvaro Ricardo de Souza. Habermas e o direito brasileiro. Rio de Janeiro: Lumen Juris, 2006 DALY, Erin. Dignity rights: courts, constitutions and the worth of the human person. Philadelphia: University of Pennsylvania Press, 2013

EGIDY, Stefanie. Casenote: the fundamental right to guarantee of a subsistence minimum in the Hartz IV Decision of the German Federal Constitutional Court. Disponível em: <http://www.germanlawjournal.com>. Acesso em: 13 ago. 2015.

FABRE, Cecile. Social rights under the Constitution. Oxford: Oxford University Press, 2000.

FERRAZ, Octavio L. Mottta. Brazil: health inequalities, rights and courts: the social impact of the judicialization of health. In: YAMIN, Alicia Ely; GLOPPEN, Siri (eds.). Litigating health rights: can courts bring more justice to health? Cambridge: Harvard University Press, 2011.

FONTE, Felipe de Melo. Políticas públicas e direitos fundamentais. São Paulo: Saraiva, 2013. 
GARGARELLA, Roberto. Dialogic justice in the enforcement of social rights: some initial arguments. In: YAMIN, Alicia Ely; GLOPPEN, Siri. Litigating health rights: can courts bring more justice to health? Cambridge: Harvard University Press, 2011.

GEWIRTH, Alan. Duties to fulffill the human rights of the poor. In: POGGE, Thomas (Ed.). Freedom from poverty as a human right. Oxford: Oxford University Press, 2005.

HABERMAS, Jürgen. O Estado Democrático de Direito: uma amarração paradoxal de princípios contraditórios?. In: Era das transições. Trad. Flávio Beno Siebeneichler. Rio de Janeiro: Tempo Brasileiro, 2003.

Sobre a coesão interna entre Estado de direito e democracia. In: A inclusão do outro: estudos de teoria política. Trad. George Sperber e Paulo Astor Soethe. São Paulo: Edições Loyola, 2002

HUAROTO. Beatriz May Ling Ramírez. Estado de cosas inconstitucional y sus posibilidades como herramienta para el litigio estratégico de derecho público: una mirada en la jurisprudencia colombiana y peruana. 2013. Dissertação (Mestrado em Direito) - Pontifícia Universidade Católica do Peru, Lima, 2013.

KRELL, Andreas J. Direitos sociais e controle judicial no Brasil e na Alemanha: os (des)caminhos de um direito constitucional "comparado". Porto Alegre: Sergio Antonio Fabris, 2002.

LEIVAS, Paulo Gilberto Cogo. O direito fundamental à alimentação: da teoria das necessidades ao mínimo existencial. In: PIOVESAN, Flávia; CONTI, Irio Luiz (orgs.). Direito humano à alimentação adequada. Rio de Janeiro: Lumen Juris, 2007

Teoria dos direitos fundamentais sociais. Porto Alegre: Livraria do Advogado, 2006.

LEMAITRE, Julieta. El Coronel sí tiene quien le escriba: la tutela por mínimo vital en Colombia. SELA Papers, Yale Law School Legal Scolarship Repository, 2005.

LOURENÇO, Daniel Braga. Direito dos animais: fundamentação e novas perspectivas. Porto Alegre: Sérgio Antonio Fabris Editor, 2008

MICHELMAN, Frank. Brennan and democracy. Princeton: Princeton University Press, 1999.

Constitutional welfare rights and a theory of justice. In: DANIELS, Norman (ed.). Reading Rawls: critical studies on Rawls' a theory of justice. Stanford: Stanford University Press, 1989

MOLINARO, Carlos Alberto et al. (orgs.). A dignidade da vida e os direitos fundamentais para além dos humanos: uma discussão necessária. Belo Horizonte: Fórum, 2008

MÜLLER, Friedrich. Que grau de exclusão social ainda pode ser tolerado por um regime democrático?. In: PIOVESAN, Flávia (coord.). Direitos humanos, globalização econômica e integração regional. São Paulo: Max Limonad, 2002.

MURALIDHAR, R. India: The Expectations and Challenges of Judicial Enforcement of Social Rights. In: LANGFORD, Malcolm (Ed.). Social rights jurisprudence: emerging trends in international and comparative law. Cambridge: Cambridge University Press, 2008.

NOZICK, Robert. Anarquia, estado e utopia. Trad. Ruy Jungmann. Rio de Janeiro: Zahar, 1994. 
NUSSBAUM, Martha C. Frontiers of justice: disability, nationality, species membership. Cambridge: The Belknapp Press of Harvard University Press, 2006.

Creating capabilities: the human development approach. Cambridge: The Belknapp Press of Harvard University Press, 2011.

PEREIRA, Potyara A. Necessidades humanas: subsídios à crítica dos mínimos sociais. 6. ed. São Paulo: Cortez Editora, 2000.

PEREIRA, Jane Reis Gonçalves. Interpretação constitucional e direitos fundamentais. Rio de Janeiro: Renovar, 2009.

PISARELLO, Gerardo. Los derechos sociales y sus garantias: elementos para una reconstrucción. Madrid: Editorial Trotta, 2007.

PONTES DE MIRANDA. Direitos à subsistência e direito ao trabalho. Rio de Janeiro: Ed. Alba Limitada, 1933.

Os novos direitos do homem. Rio de Janeiro: Ed. Alba Limitada, 1933.

RAWLS, John. A theory of justice. Cambridge: The Belknap Press of Harvard University Press, 1971. O liberalismo político. Trad. Álvaro de Vita. São Paulo: Martins Fontes, 2011, p. 8.

REGAN, Tom. The case for animal rights. Berkeley: University of California Press, 2004.

ROSE-ACKERMAN, Susan. Análise econômica progressista do direito: e o novo direito administrativo. In: MATTOS, Paulo; PRADO, Mariana Mota; ROCHA, Jean Paul Cabral Veiga (orgs.). Regulação econômica e democracia: o debate norte-americano. São Paulo: Editora 34, 2004.

SARLET, Ingo Wolfgang. Direitos fundamentais e direito privado: algumas considerações em torno da vinculação dos particulares aos direitos fundamentais. In: (org.). A Constituição concretizada. Porto Alegre: Livraria do Advogado, 2000.

Direitos fundamentais sociais, mínimo existencial e direito privado: breves notas sobre alguns aspectos da possível eficácia dos direitos sociais nas relações entre particulares. In: SARMENTO, Daniel; GALDINO, Flávio (orgs.). Direitos fundamentais: estudos em homenagem ao Professor Ricardo Lobo Torres. Rio de Janeiro: Renovar, 2006.

Notas a respeito do direito fundamental à moradia na jurisprudência do Supremo Tribunal Federal. In: SARMENTO, Daniel; SARLET, Ingo Wolfgang (coords.). Direitos fundamentais no Supremo Tribunal Federal: balanço e crítica. Rio de Janeiro: Lumen Juris, 2011.

Os direitos sociais na Constituição de 88. In: (org.). O direito público em tempos de crise: estudos em homenagem a Ruy Ruben Ruschel. Porto Alegre: Livraria do Advogado, 1999.

SARLET, Ingo Wolfgang; FENSTERSEIFER, Tiago. Estado socioambiental e mínimo existencial (ecológico?): algumas aproximações. In: SARLET, Ingo Wolfgang (org.). Estado socioambiental e direitos fundamentais. Porto Alegre: Livraria do Advogado, 2010.

SARLET, Ingo Wolfgang; FIGUEIREDO, Mariana Filchtiner. Reserva do possível, mínimo existencial e direito à saúde: algumas aproximações. In: SARLET Ingo Wolfgang; TIMM, Luciano Benetti (orgs.). Direitos fundamentais, orçamento e 'reserva do possível'. Porto Alegre: Livraria do Advogado, 2008. 
SARLET, Ingo Wolfgang; TIMM, Luciano Benetti (orgs.). Direitos fundamentais, orçamento e "reserva do possível”. Porto Alegre: Livraria do Advogado, 2008.

SARMENTO, Daniel (orgs.). Direitos sociais: fundamentos, judicialização e direitos sociais em espécie. Rio de Janeiro: Lumen Juris, 2008

Direitos fundamentais e relações privadas. 2. ed. Rio de Janeiro: Lumen Juris, 2010

A proteção judicial dos direitos sociais: alguns parâmetros ético-jurídicos. In: SOUZA NETO, Cláudio Pereira de; SARMENTO, Daniel (orgs.). Direitos sociais: fundamentos, judicialização e direitos sociais em espécie. Rio de Janeiro: Lumen Juris, 2008

SILVA, Virgílio Afonso da. A constitucionalização do direito: os direitos fundamentais nas relações entre particulares. São Paulo: Malheiros, 2005.

Direitos fundamentais: conteúdo essencial, restrições e eficácia. São Paulo: Malheiros, 2009

O judiciário e as políticas públicas: entre transformação social e obstáculo. In: SOUZA NETO, Cláudio Pereira de; SARMENTO, Daniel (orgs.). Direitos sociais: fundamentos, judicialização e direitos sociais em espécie. Rio de Janeiro: Lumen Juris, 2008

SOUZA NETO, Cláudio Pereira de. Teoria constitucional e democracia deliberativa. Rio de Janeiro: Renovar, 2006.

SPENCER, Herbert. Social Statics. In: SCHAPIRO, J. Salwin (ed.). Liberalism: its meaning and history. New York: Van Nostrand Reinhold, 1958.

STEINMETZ, Wilson Antônio. Vinculação dos particulares aos direitos fundamentais. São Paulo: Malheiros, 2005

SUNSTEIN, Cass; HOLMES, Stephen. The cost of rights: why liberty depends on taxes. New York: W.W. Norton and Company, 1999

TORRES, Ricardo Lobo. A metamorfose dos direitos sociais em mínimo existencial. In: SARLET, Ingo Wolfgang (org.). Direitos fundamentais sociais: estudos de direito constitucional, internacional e comparado. Rio de Janeiro: Renovar, 2003.

O direito ao mínimo existencial. Rio de Janeiro: Renovar, 2009

TUGENDHAT, Ernst. Lições sobre ética. Trad. Róbson Ramos dos Reis et al. 4. ed. Petrópolis: Editora Vozes, 2000

VIEIRA, Oscar Vilhena. A Constituição e sua reserva de justiça: um ensaio sobre os limites materiais ao poder de reforma. São Paulo: Malheiros, 1999.

ZAMBITTE, Fábio. A previdência social no estado contemporâneo. Niterói: Impetus, 2011

\section{JURISPRUDÊNCIA}


ÁFRICA DO SUL, Corte Constitucional. Government of the Republic of South Africa and Others v. Grootboom and Others (CCT11/00) [2000] ZACC 19; 2001 (1) SA 46; 2000 (11) BCLR 1169 (4 October 2000).

ALEMANHA, Tribunal Administrativo Federal. BVerwGE 1, 159 (1954).

Tribunal Constitucional Federal. BVerfGE 125, 175 (2010).

Tribunal Constitucional Federal. BVerfGE 33, 303 (1972).

Tribunal Constitucional Federal. BVerfGE 40, 121 (1975).

BRASIL, Superior Tribunal de Justiça, 1a Seção, Ag. Reg no REsp. 889.010, Rel. Min Luiz Fux, julg. 20.10.2009.

Superior Tribunal de Justiça, 1ạ Seção, Ag Reg. nos Emb. Div. no REsp 881.879, Rel. Min. Luiz Fux, julg. 25.11.2009.

Superior Tribunal de Justiça, 2a Turma, AgRg no REsp 1217839, Rel. Min. Castro Meira, julg. 18.11.2011; e 2a Turma, AgRg no REsp 1182130, Rel. Min. Castro Meira, julg. 18.11.2010.

Superior Tribunal de Justiça, 2a Turma, REsp 1.185.474, Rel. Min. Humberto Martins, julg. 20.04.2010.

Superior Tribunal de Justiça, 3a Turma, REsp 1191195, Rel. p. ac. Min. Ricardo Villa Boas Cuevas, julg. 12.03.2013.

Superior Tribunal de Justiça, 3a Turma. Ag no REsp 1206956, Rel. Min. Paulo de Tarso Sanseverino, julg. 18.10.2012.

Superior Tribunal de Justiça, 4ạ Turma, Rel. Min. Luis Felipe Salomão, julg. 03.03.2015.

Superior Tribunal de Justiça, REsp 1231123, 3a a Turma, Rel. Min. Nancy Andrighi, julg. 02.08.2012.

Superior Tribunal de Justiça, Segunda Seção, REsp 1230060, Rel. Min. Maria Isabel Gallotti, julg. 13.08.2014.

Superior Tribunal de Justiça. 2a Turma, REsp 1366331, Rel. Min. Humberto Martins, julg. 16.12.2014.

Superior Tribunal de Justiça. 4ạ Turma, REsp 950663, Rel. Min. Luis Felipe Salomão. Julg. 10.04.2012.

23.08.2011.

Superior Tribunal de Justiça, ADPF 45 - MC, Rel. Min. Celso de Mello, julg. 29.04.2004

Superior Tribunal de Justiça, RE 273.834, Rel. Min. Celso de Mello, D.J. 18.09.2000.

Superior Tribunal de Justiça, RE 592.581, Rel. Min. Ricardo Lewandowski, julg. 13.08.2015.

BRASIL, Supremo Tribunal Federal. 1a Turma, AgReg no RE 658171, Rel. Min. Dias Toffoli, julg. 01.04.2014.

Superior Tribunal de Justiça 2a Turma, AgReg no RE 639.337, Rel. Min. Celso de Mello, julg. 23.08.2011.

Superior Tribunal de Justiça ADPF 347 - MC, Rel. Min. Marco Aurélio, julg. 09.09.2015.

Superior Tribunal de Justiça ADPF 45 MC, Rel. Min. Celso de Mello, julg. 29.04.2004.

Superior Tribunal de Justiça. Plenário, ADI 1.442, Rel. Min. Celso de Mello, julg. 3.11.2004.

COLÔMBIA, Corte Constitucional, Sentencia SU 090/2000.

Corte Constitucional, Sentencia T-025/2014.

Corte Constitucional,Sentencia T-153/1998.

Corte Constitucional,T-888/08, T-418/10, T-028/14

Corte Constitucional, Sentencia C-776/2003. 
ESTADOS UNIDOS, Suprema Corte. Lochner v. New York. 198 U.S. 45 (1905).

ISRAEL, Suprema Corte. Hasan v. The Social Security Institution, julg. 28.02.2012.

PORTUGAL, Tribunal Constitucional. Acórdão 318/99, Relator Conselheiro Vitor Nunes de Almeida.

SÃO PAULO, Tribunal de Justiça do Estado. Apelação n. 0150735-64.2008.8.26.0002, Câmara Especial, Rel. Des. Walter de Almeida Guilherme, julg. 16.12.2013.

Trabalho enviado em 14 de outubro de 2016.

Aceito em 28 de outubro de 2016. 